\title{
Poznohalštatska grobova s Kovka nad Hrastnikom v Zasavju
}

\section{Late Hallstatt burials from Kovk above Hrastnik, in the Zasavje region (central Slovenia)}

\author{
Dragan BOŽIČ, Andrej GASPARI, Darja PIRKMAJER
}

\section{Izvleček}

Leta 2015 je bila v Vrtači pod vrhom hriba Kovk nad Hrastnikom naključno odkrita skupina kovinskih predmetov, ki vključuje negovsko čelado, kavljasto pasno spono in druge dele pasne oprave ter tulasto sekiro. Predmete je pridobil Pokrajinski muzej Celje, ki je avgusta 2016 izvedel kontrolno izkopavanje. Odkrit je bil skeletni grob bojevnika z dodatnimi deli pasne oprave, odlomkoma fibule in sulične osti ter stekleno jagodo. Tik ob njem je bil izkopan skeletni grob dekleta z ogrlico iz steklenih jagod, zapestnicama in nanožnicama ter nožičkom.

Med predmeti izstopata negovska čelada različice Vače slovenske vrste in pasna oprava vrste Kovk z izjemno kavljasto spono. Najmlajši grobni pridatki določajo čas pokopa obeh oseb v starejšem delu negovske stopnje.

Grobova pripadata planemu grobišču pod manjšo utrjeno naselbino na vrhu Kovka. Skupaj s skupino gomil na ledini Grobišče pri Kovku dopolnjujeta vedenje o železnodobni poselitvi Zasavja.

Ključne besede: Kovk nad Hrastnikom; dolenjska skupina halštatske kulture; utrjene višinske naselbine; plana grobišča; negovske čelade; pasne oprave

\footnotetext{
Abstract

Several metal artefacts came to light in 2015 at Vrtača, a site below the summit of the Kovk hill above Hrastnik. It was a chance find that comprised a Negova helmet, parts of a belt including a hook plate and a socketed axe. The Pokrajinski muzej Celje acquired the artefacts and also investigated the site in 2016. An inhumation burial of a warrior was discovered with additional parts of the belt, a fragment of a fibula and one of a spearhead, as well as a glass bead. Next to it was an inhumation burial of a girl with a necklace of glass beads, pair of bracelets, pair of anklets and a small knife.

The grave goods include two significant artefacts. One is a Negova helmet of the Slovenian type, variant Vače, the other a Kovk type belt set with an exceptional hook belt plate. The goods that are latest in date place the burial of both individuals to the early part of the Negova phase.

The burials form part of a flat cemetery below the summit of Kovk that held a small hillfort. Together with the group of tumuli at Grobišče, south of the Kovk village that lies southeast of the Kovk hill, they shed additional light on the Iron Age settlement in the Zasavje region of Slovenia.

Keywords: central Slovenia; Kovk above Hrastnik; Dolenjska Hallstatt cultural group; hillforts; flat cemeteries; Negova helmets; belt sets
} 


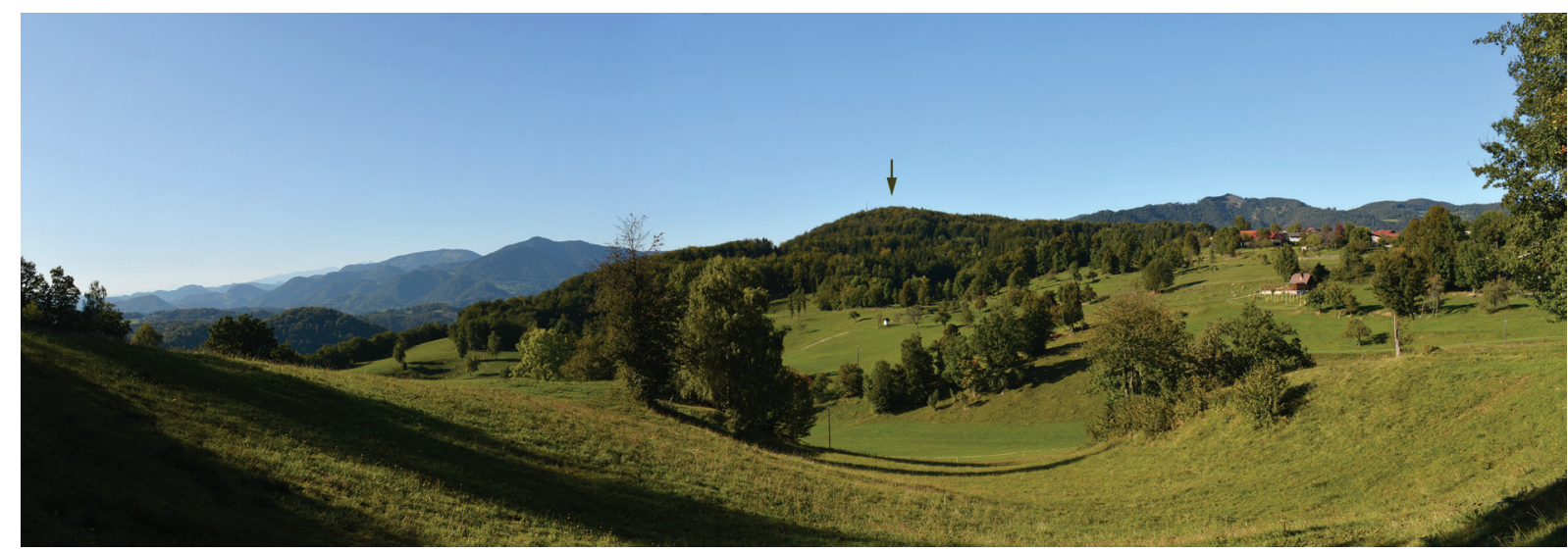

Sl. 1: Pogled na hrib Kovk nad Hrastnikom s severnega pobočja vzpetine Vrh nad Krnicami.

Fig. 1: The hill of Kovk above Hrastnik viewed from the north slope of Vrh above Krnice.

\section{OKOLIŠČINE ODKRITJA IN ZAČETNE RAZISKAVE}

Jeseni leta 2015 so bile vzhodno od vrha hriba Kovk nad Hrastnikom v gozdni vlaki na severnem delu ene izmed vrtač (v nadaljevanju imenovane Vrtača) odkrite pomembne arheološke najdbe ( $s l$. $1 ; 2: 2$ ). Obsegale so ritualno poškodovano čelado, dele pasne oprave, sekiro in sulično ost, ki je takoj po dvigu razpadla. O odkritju je bil obveščen Pokrajinski muzej Celje (PM Celje). Ker je sestava najdb omogočala domnevo, da predstavljajo del inventarja moškega skeletnega pokopa iz pozne halštatske dobe, je muzejska ekipa februarja 2016 opravila ogled najdišča in njegove širše okolice, pri čemer so bili na vrhu Kovka ugotovljeni ostanki dotlej neznane železnodobne naselbine (sl. 2: 1). ${ }^{1}$

Najdeni predmeti so bili julija 2016 uvrščeni v zbirke PM Celje, novi najdišči pa sta bili na predlog Območne enote Celje Zavoda za varstvo kulturne dediščine Slovenije vpisani v register nepremične kulturne dediščine pod EŠD 30325 Kovk pri Hrastniku - prazgodovinska naselbina.

$\mathrm{Z}$ namenom pridobitve podrobnejših podatkov o najdiščih na Kovku je ekipa PM Celje pod vodstvom Darje Pirkmajer s finančno podporo Ministrstva za kulturo Republike Slovenije med 8. in 12. avgustom 2016 opravila testni izkop na sporočenem mestu odkritja pridobljenih predmetov na severnem delu

1 Andrej Gaspari, Strokovno mnenje o pristnosti in pomenu konvoluta poznohalštatskih kovinskih predmetov s Kovka v Zasavju, Ljubljana, februar 2016 (tipkopis); Darja Pirkmajer in Maja Bausovac, Poročilo o arheološkem testnem izkopu na lokaciji Kovk (16-0231), Celje, oktober 2016 (tipkopis), hrani Pokrajinski muzej Celje.
Vrtače (sonda 1), med 16. avgustom in 4. oktobrom 2016 pa še manjša sondažna izkopa na območju domnevanega obzidja na južnem (sonda 2 - vel. $2,5 \times 2,5 \mathrm{~m}$ ) oz. jugovzhodnem robu (sonda 3 vel. $2,5 \times 0,7 \mathrm{~m})$ spodnje terase gradišča $(s l .3)$.

\section{GRADIŠČE KOVK}

Ostanki prazgodovinske naselbine razpotegnjene ovalne oblike z obsegom okoli $460 \mathrm{~m}$ in površino okoli 0,9 ha (sl. 3) ležijo na zložnem južnem pobočju vrha Kovka $(659 \mathrm{~m})$ severozahodno od istoimenske vasi. V smeri proti zahodu in severu so strma, ponekod prepadna skalna pobočja, ki so naselbini nudila dobro naravno zaščito in padajo proti okoli 400 metrov nižje ležečima dolinama potokov Brnice in Bobna.

Proti jugu, kjer je pobočje položnejše, in proti vzhodu je bila naselbina zavarovana $\mathrm{z}$ obzidjem. Dobro je viden zlasti njegov južni potek, na površini zaznaven kot oster terasast prelom terena, ki preide na vzhodu v nizek okop.

Sondiranje na južnem robu terase (sonda 2) je pokazalo skromno ohranjenost obzidja v obliki $50-60 \mathrm{~cm}$ širokega suhozida $\mathrm{z}$ ravnima licema iz večjih kamnov in vmesnim kamnitim drobirjem. Grajen je bil neposredno na skalno podlago, ki se je pojavila $\mathrm{v}$ globini $40 \mathrm{~cm}$ pod današnjo površino (sl. 4). V sondi 3 je bila na mestu, kjer naj bi potekal suhozid, večja količina kamenja. $\mathrm{V}$ obeh sondah so bili v črni kulturni plasti najdeni odlomki starejšeželeznodobne keramike.

Nekaj deset metrov pod gradiščem se proti jugu in vzhodu širi ravnica, gosto posejana $z$ vrtačami, ki proti jugovzhodu prehaja $\mathrm{v}$ obsežno planoto. 


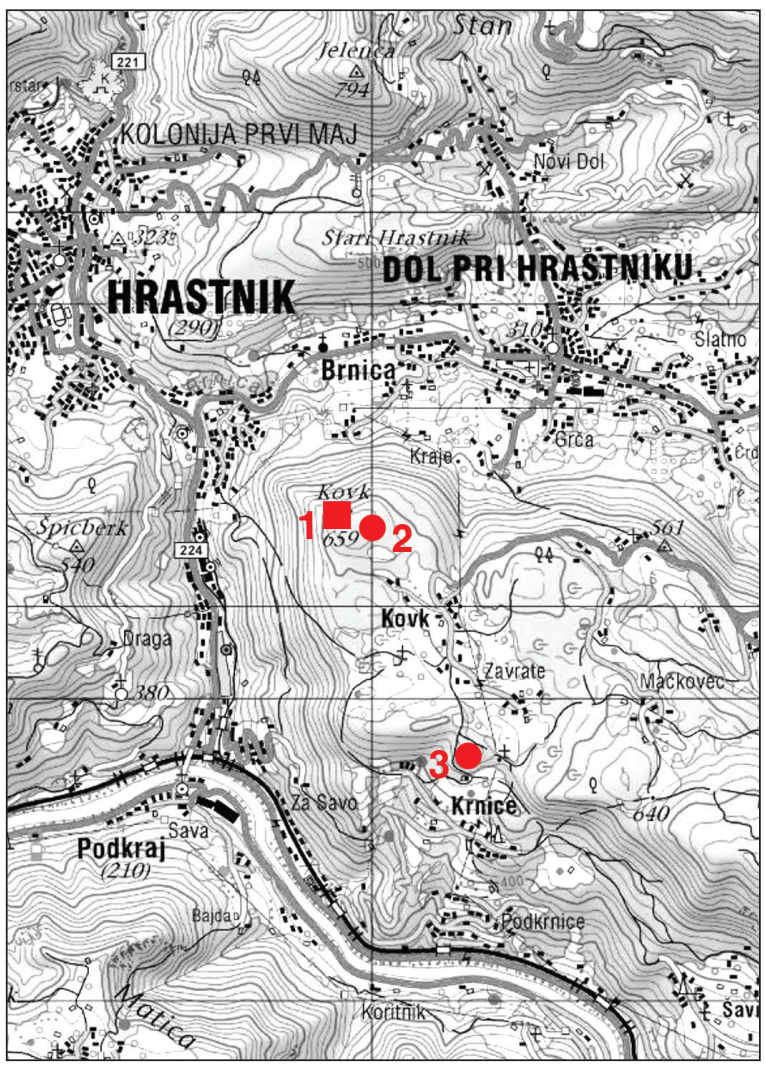

Sl. 2: Lega gradišča Kovk (1), planega grobišča v Vrtači pri Kovku (2) in gomilne nekropole Grobišče pri Kovku (3). M. = 1:50000.

Fig. 2: Location of the hillfort on Kovk (1), the flat cemetery at Vrtača near Kovk (2) and the tumulus cemetery at Grobišče near Kovk (3). Scale $=1: 50000$.

(Kartografska podlaga / Base map TDK 25: Trbovlje @ GURS)

Ta domnevno predstavlja gospodarsko zaledje železnodobne naselbine, ki ga še danes obvladujeta dva manjša zaselka (sl. 2-3).

S svojo lego se gradišče uvršča med višje ležeče utrjene naselbine starejše železne dobe dolenjske skupine. ${ }^{2}$ Okvirno kronološko umestitev v halštatsko dobo nakazujejo odlomki prostoročno izdelanih posod, odkriti v obeh sondah na območju obzidja in $\mathrm{v}$ profilu vlake pod južnim robom gradišča.

\section{GOMILNO GROBIŠČE PRI KOVKU}

Poselitvi gradišča na vrhu Kovka je sočasno približno $1,3 \mathrm{~km}$ zračne črte oddaljeno gomilno grobišče, poimenovano Grobišče pri Kovku (sl. 2: 3). Leži na južnem robu planote Kovka na gozdnati vzpetini (590 m), ki se dviga nad zaselkom Zagorica

${ }^{2}$ Dular, Tecco Hvala 2007, 74.

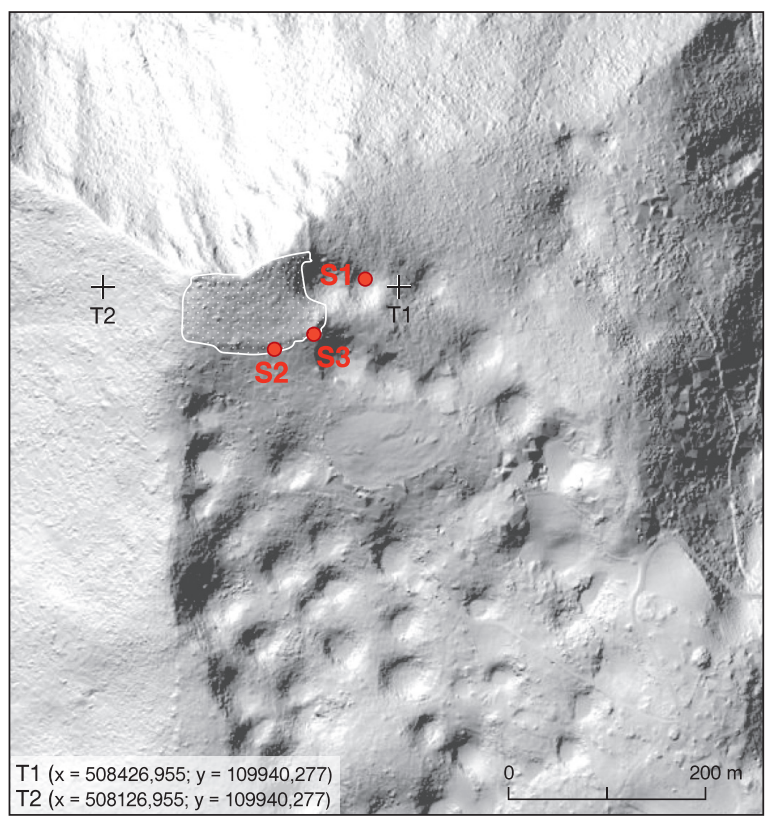

Sl. 3: Lidarski posnetek z označeno naselbino in lego sond na Kovku. M. = 1:10000.

Fig. 3: Lidar image with marked settlement and trial trenches on Kovk. Scale $=1: 10000$. (LIDAR (c) ARSO)

in domačijo Grčar v Krnicah. ${ }^{3}$ Grobišče obsega 5 ali $6^{4}$ gomil na parceli št. $1143 / 2 \mathrm{k}$. o. Gore.

Prvi ga je omenil Balduin Saria leta 1937 v objavi rimskega nagrobnika s keltskimi imeni, ${ }^{5}$ ki so ga pod parcelo $\mathrm{z}$ gomilami maja tega leta našli delavci pri iskanju materiala za popravilo občinske ceste. Lastnik gozdne parcele je bil takrat Franc Urbajs, p. d. Grčar, Sv. Jurij 46. Saria pripisuje grobišče južno od njega ležeči vasi Krnice. Od domačinov je izvedel, da je bila ena gomila razkopana že leta 1913 in da so takrat našli dve zapestnici, "okroglo ploščo iz brona z luknjami", sulične osti, 6 loncev in več "balzamarijev". $\mathrm{Na}$ podlagi teh najdb je domneval, da so gomile iz

${ }^{3} \mathrm{~V}$ Arheoloških najdiščih Slovenije Lojze Bolta gomile in v njih odkrite najdbe omenja na treh mestih: pri vasi Kovk v topografski enoti Dol pri Hrastniku ter pri vasi Krnice in njenem zaselku Zagorice (prav Zagorica) v topografski enoti Hrastnik (Bolta 1975). Najdbe, omenjene pod najdišči Kovk in Zagorice, se nanašajo na kopanje Ivana Restarja leta 1938, odlomek zapestnice, naveden pod najdiščem Krnice, pa na najdbe iz gomile, ki je bila razkopana leta 1913. Ni jasno, zakaj Bolta vsaj pri najdišču Kovk ni omenil svojih sondiranj v tamkajšnjih gomilah v letu 1955.

${ }^{4}$ Leta 1955 je bilo po načrtu v terenskem dnevniku Bolte in po njegovem načrtu gomil na Kovku vidnih šest gomil. Na načrtu, ki je nastal v sklopu projekta Utrjena prazgodovinska naselja na Dolenjskem, jih je označenih pet (Dular, Tecco Hvala 2007, 258, kat. št. 21, sl. 153).

5 Saria 1937, 133. 


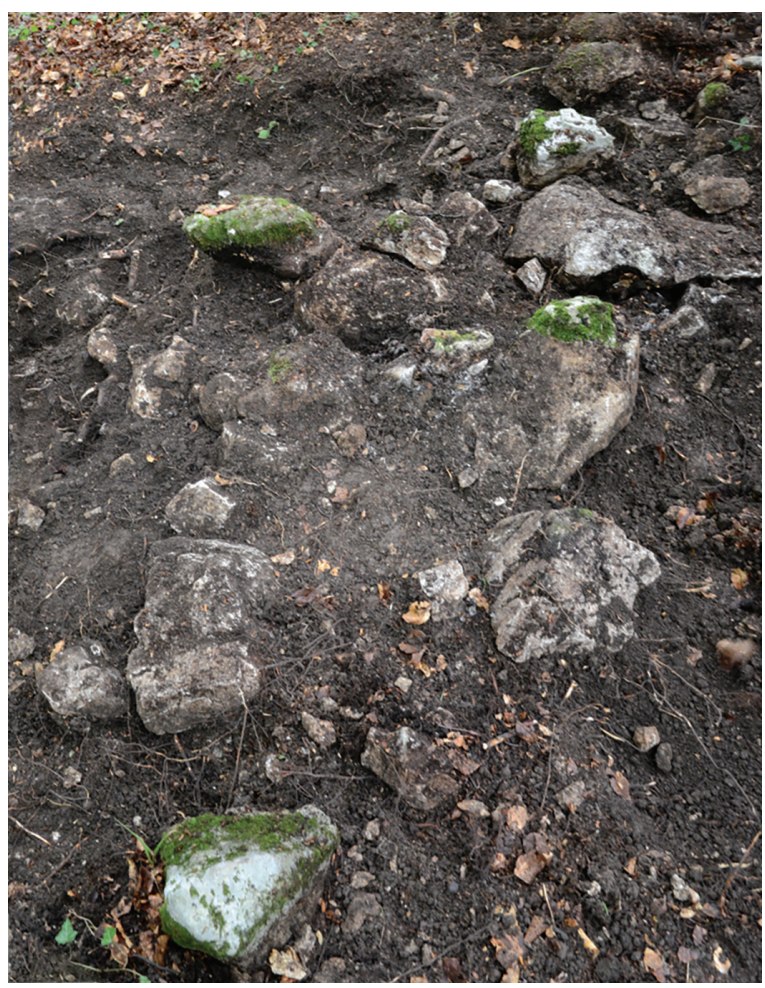

Sl. 4: Gradišče Kovk. Ostanki suhozida v sondi 2.

Fig. 4: The hillfort on Kovk. Drywall remains in Trench 2.

rimske dobe. Vendar je zelo malo verjetno, da so bili v njih najdeni balzamariji, saj že omemba suličnih osti nakazuje halštatsko starost gomil. To kaže tudi odlomek bronaste zapestnice, ki je bil po Sarii edina ohranjena najdba iz leta 1913. Da gre za odlomek zapestnice, ki ga pod inv. št. P 12296 hrani Narodni muzej Slovenije (sl. 5: 1), dokazuje vpis $\mathrm{v}$ inventarni knjigi, $\mathrm{v}$ katerem so kot najdišče navedene Krnice pri Hrastniku, kot leto najdbe pa 1913.

Podatke o gomilnem grobišču pri vasi Kovk dopolnjuje članek Hrastničana Lojzeta Hofbauerja (Hofbauer 1955), v katerem je prvič zapisano, da je gozd posestnika Grčarja, v katerem ležijo (gomilni) grobovi, na Kovku nad Hrastnikom. Pisec navaja, da so domačini že pred drugo svetovno vojno razen bronastih zapestnic in posod našli tudi steklene ovratnice, s čimer je gotovo mislil na ogrlice iz steklenih jagod, pogost pridatek ženskih grobov halštatske dobe.

$\mathrm{V}$ članku zasledimo tudi podatek, ki dokazuje, da z obravnavanega grobišča izvirajo tudi odlomki mladohalštatskega ciborija v Narodnem muzeju Slovenije, ki ima inv. št. P 10499 (sl. 5: 2). $\mathrm{V}$ inventarni knjigi je namreč poleg navedbe, da je bila posoda najdena novembra 1938 na Kovku pri Hrastniku, še pripis "selo Podkrnica Restar".
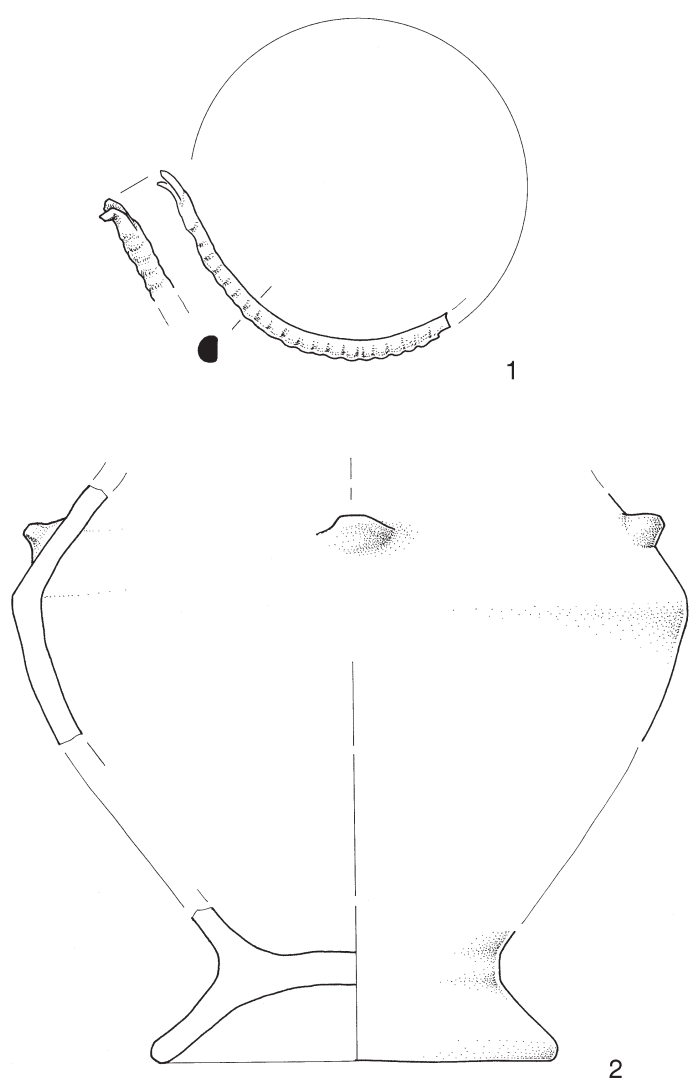

Sl. 5: Grobišče pri Kovku. Najdbi iz gomil. 1 bron; 2 keramika. $\mathrm{M} .1=1: 2 ; 2=1: 3$.

Fig. 5: Grobišče near Kovk. Grave goods from the tumuli. 1 bronze; 2 ceramics. Scale $1=1: 2 ; 2=1: 3$.

Na kaj se nanaša, pojasnjuje navedba $v$ članku, da je v Grčarjevem gozdu tik pred izbruhom druge svetovne vojne izkopaval Ivan Restar iz zaselka Podkrnice, ki je o tem obvestil Narodni muzej v Ljubljani. Grobišče si je prišel ogledat kustos Rajko Ložar, ki je ugotovil, da je staro okrog 2500 let, in povedal, da nekaj tam izkopanih predmetov hranijo v muzejski zbirki. Hofbauer nadalje poroča, da je leta 1955 na grobišču na Kovku v zvezi z načrtovano ustanovitvijo muzeja v Hrastniku potekalo izkopavanje pod vodstvom celjskega kustosa Lojzeta Bolte, pri katerem pa niso našli ničesar več.

Nekaj podrobnosti o tridnevnih izkopavanjih, ki so potekala od 23. do 25. maja, izvemo iz Boltovega terenskega dnevnika in približnega načrta grobišča, na katerem je skiciranih šest gomil (I-VI). ${ }^{6}$ Sondiranje izredno dolge in razmeroma ozke "sedme gomile" je namreč pokazalo, da gre za naravno tvorbo. Sonde so napravili še v dveh gomilah, ki ju je v dnevniku označil z a (št. VI na

${ }^{6}$ Dokumentacijo hrani PM Celje. 
načrtu) in b (št. II na načrtu). Nobena od dveh sond $\mathrm{v}$ gomili a, prečna na sredini in podolžna na južnem koncu, ni dala rezultata. Zadnja sonda je bila narejena $\mathrm{v}$ gomili $\mathrm{b}$, ki je bila po pripovedi domačinov kopana že leta 1938 ali 1939. Gre torej za gomilo, ki jo je načel Ivan Restar. V tej sondi so naleteli na dva različno dolga niza kamnov, ki sta se zgoraj stikala tako, da sta tvorila ostri kot. Krajši niz je bil dolg približno $1 \mathrm{~m}$. Pod kamni ni bilo najdb.

Glede na vse povedano gre za grobišče z jasno vidnimi gomilami. Od najdenih grobnih pridatkov so se ohranili samo odlomek narebrene bronaste zapestnice in črepinje ciborija (sl. 5). Na podlagi tega lahko gomilno grobišče okvirno datiramo v mlajšo halštatsko dobo.

\section{PLANO GROBIŠČE V VRTAČI PRI KOVKU}

Novoodkrito grobišče leži v Vrtači na pobočju vzhodno od železnodobne naselbine na vrhu Kovka (sl. 2: 2; 3). Že pri ogledu terena je bilo ugotovljeno, da gre za plano grobišče. Arheološko sondiranje je bilo opravljeno leta $2016 \mathrm{v}$ severnem delu Vrtače na mestu, kjer so bile leto prej odkrite prve najdbe. Raziskava je bila osredotočena na dokumentiranje groba s čelado, pri čemer pa je bil v njegovi neposredni bližini odkrit še dekliški grob. Obseg grobišča ostaja neznan in bo predmet prihodnjih raziskav.

Sonda 1 je bila velika $2,7 \times 2,85 \mathrm{~m}$ in na severovzhodni strani dodatno razširjena $\mathrm{z} 0,7 \times 0,9 \mathrm{~m}$ (sl. 6). Izkop je segel do sterilne ilovnate, mestoma skalne podlage, ki se je pojavila $\mathrm{v}$ globini $0,6 \mathrm{~m}$. Pri tem je bil dobro viden vkop, ki je nastal pri odkritju dela grobnega inventarja.

$\mathrm{V}$ sondi so našli moški skelet s preostalimi pridatki in dekliški skelet s pripadajočim nakitom. Ker se ilovnato zasutje ob skeletih ni razlikovalo od okolice, grobne jame niso bile vidne. Zato ni bilo mogoče ugotoviti, ali gre za dvojni grob v eni sami grobni jami ali za dva ločena grobova. Glede na isto usmeritev obeh okostij in domnevno sočasnost pridatkov sta se avtorici poročila nagibali $\mathrm{k}$ sklepu, da gre za dvojni grob, razliko v globini lege skeletov pa pojasnili z različno višino skalne podlage. ${ }^{7}$ Kljub temu sta predstavili oba pokopa kot samostojni grobni celoti, označeni kot grob 1 in grob 2, čemur sledi tudi ta objava.

\footnotetext{
${ }^{7}$ Glej op. 1.
}

Grob $1(t .1-5)$

Kot grob 1 je bil označen zahodni skelet odraslega moškega, ki je ležal $\mathrm{v}$ globini $25-60 \mathrm{~cm}$ pod današnjo gozdno površino. Skelet je ležal v mastni sivi ilovici v smeri sever-jug z majhnim odklonom proti zahodu in z glavo na severni strani (sl. 6).

V srednjem delu groba sta bila najdena odlomek lista železne sulične osti in noga certoške fibule. Nad desno in manjkajočo levo stegnenico je bila dobro vidna sivočrna lisa, verjetno ostanek organske podloge čelade iz usnja ali blaga. Pod njo so ležali kratek žlebičast pasni okov, drobni usločeni trakasti odlomki in odlomki podložk. Ob desni stegnenici je bil položen manjši železen nož; v grobu je bila najdena tudi modra steklena jagoda.

Od skeleta so bili ohranjeni deli lobanje, ključnici, odlomek leve lopatice, nadlahtnici, odlomek leve podlahtnice, desna stegnenica (pozelenela od brona) ter golenici in mečnici. Viden je bil odtis leve stegnenice. Starost pokojnika je bila ocenjena na 25 do 30 let (bližje 30), višina 169 $\mathrm{cm} \mathrm{z}$ razponom od 166 do $170 \mathrm{~cm}$, ugotovljene so bile patološke spremembe na okostju. Na desni temenici je vidna površinska poroznost - Hyperostosis porotica, ki nastane zaradi anemije kot posledice pomanjkanja železa. Na obeh golenicah je imel moški vnetje kosti, periostitis, ki je lahko posledica kompliciranega zloma, ugriza živali ali rane, pridobljene v boju. ${ }^{8}$

\section{Grob $2(t .6-7)$}

Manj kot meter vzhodno od groba 1 je v mastni sivi ilovici, omejeni s skalno kotanjo, ležal dekliški skelet, in sicer nekoliko višje, na globini 15 do $37 \mathrm{~cm}$ pod današnjo površino. Označen je bil kot grob 2. Tudi ta skelet je bil usmerjen sever-jug z majhnim odklonom proti zahodu in z glavo proti severu (sl. 6).

Ob glavi in pod njo je bilo najdenih 26 raznobarvnih jagod ogrlice. Na levi podlahtnici in slabo vidnem odtisu desne podlahtnice sta bili dve votli zapestnici, nad spodnjim delom leve stegnenice pa narebrena polna nanožnica s presegajočima se koncema ter enaka okrog zgornjega dela desne golenice. Na notranji strani leve nadlahtnice je

\footnotetext{
8 Antropološko analizo je opravila Zdravka Hincak z Odseka za arheologijo Filozofske fakultete Univerze v Zagrebu. Preliminarno poročilo hrani PM Celje.
} 


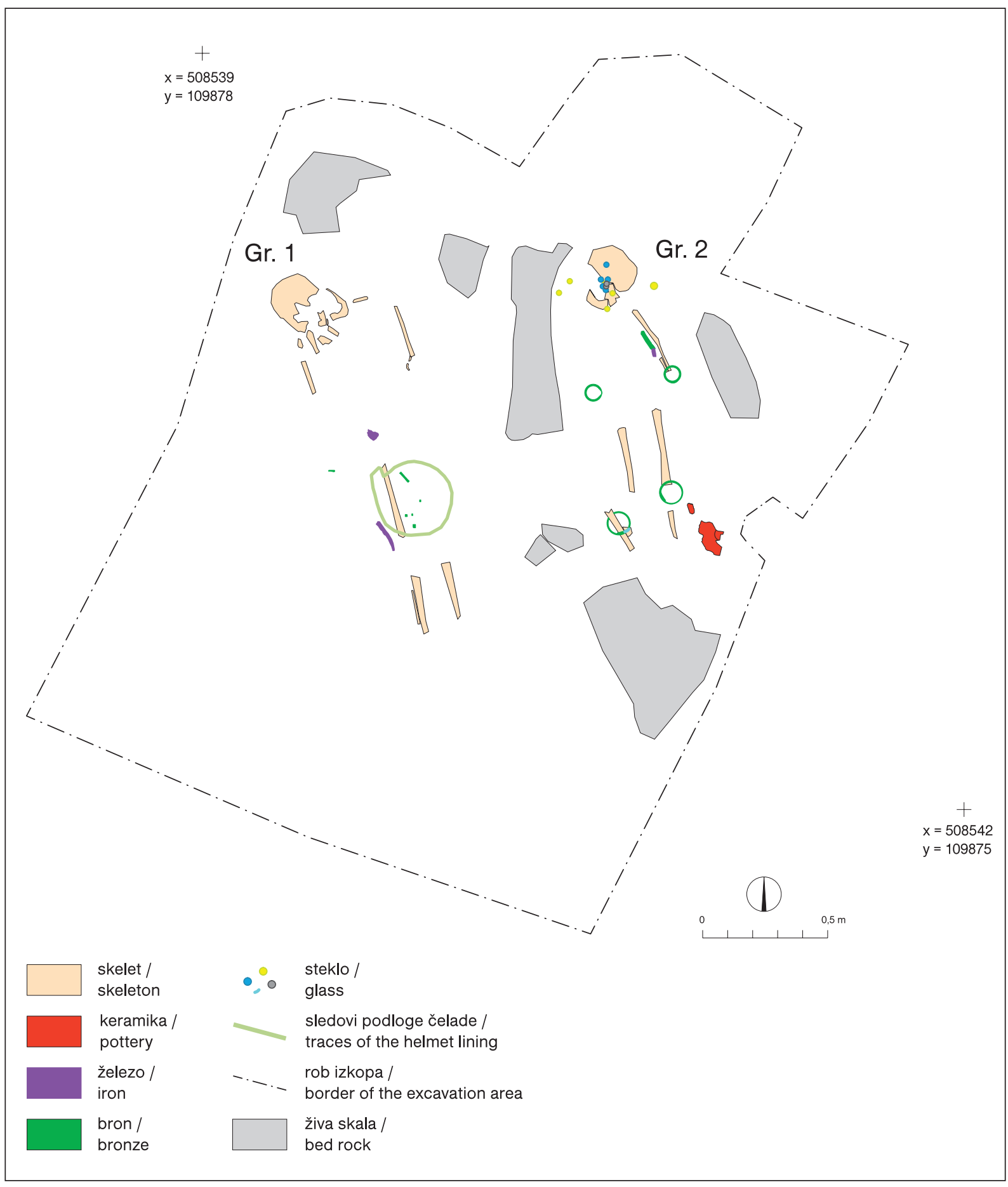

Sl. 6: Vrtača pri Kovku. Sonda 1: tloris grobov 1 in $2 \mathrm{z}$ lego pridatkov. M. = 1:25.

Fig. 6: Vrtača near Kovk. Trench 1: plan of Graves 1 and 2 with the position of the grave goods. Scale $=1: 25$.

ležal nožiček, na zunanji strani leve golenice pa ostanki dveh keramičnih posod.

Ohranjeni so bili deli lobanje, leva nadlahtnica, leva podlahtnica, leva koželjnica, stegnenici in golenici. Starost dekleta je bila po preliminarni analizi ocenjena na 13 do 15 let, višina pa na približno
$135 \mathrm{~cm}$. Patološke spremembe: na odlomku leve golenice je vidna površinska poroznost - Hyperostosis porotica, ki nastane zaradi anemije. ${ }^{9}$

\footnotetext{
${ }^{9}$ Glej op. 8.
} 
a

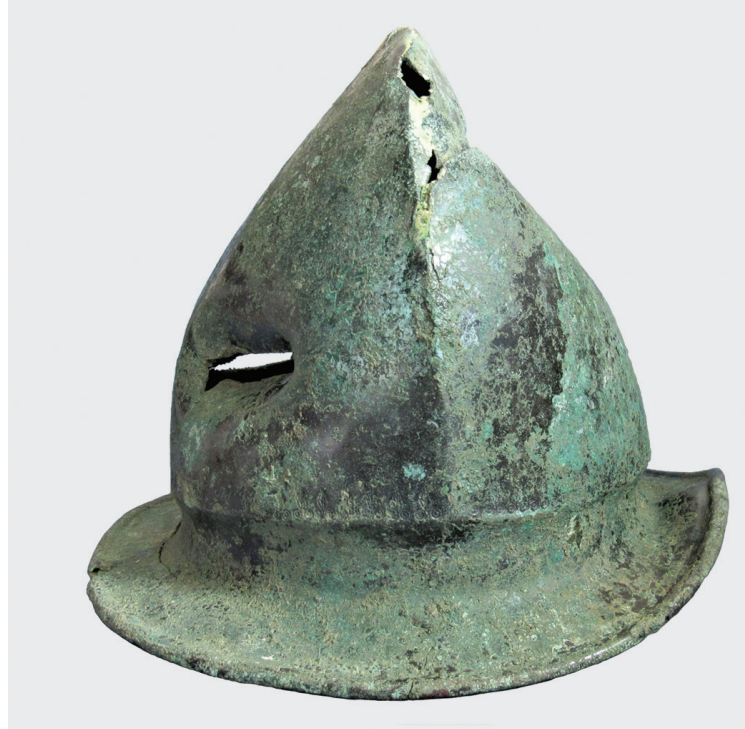

b

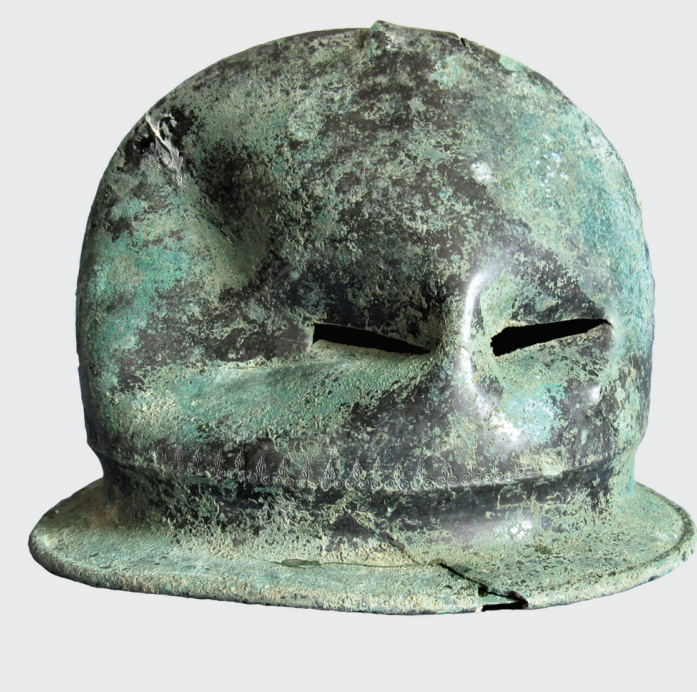

Sl. 7: Vrtača pri Kovku. Negovska čelada iz groba 1. M. $=\sim 1: 4$.

Fig. 7: Vrtača near Kovk. Negova helmet from Grave 1. Scale $=\sim 1: 4$.

\section{ANALIZA NAJDB IN ČASOVNA OPREDELITEV GROBOV V VRTAČI}

\section{Grob 1}

Od pridatkov groba 1 pridejo $\mathrm{v}$ poštev za časovno opredelitev negovska čelada, pasna oprava in noga certoške fibule.

\section{Negovska čelada}

Bronasta negovska čelada (sl. 7-8; t. 1-2; 3: 1e) se uvršča $\mathrm{v}$ posebno, skoraj v celoti na ozemlje Slovenije omejeno skupino negovskih čelad, katere najopaznejša značilnost je navznoter zapognjen rob krajcev, ki drži nosilec podloge. Stane Gabrovec jo je sprva imenoval vzhodnoalpska inačica italsko-etruščanskega tipa in pozneje jugovzhodnoalpska varianta negovskih čelad, ${ }^{10}$ Markus Egg pa slovenska vrsta negovskih čelad, ki jo je razdelil na dve različici. Prvo je imenoval različica Vače, tej pripada

10 Gabrovec 1950, 98; Gabrovec 1965a, 181-182 in 184-185. Na seznam čelad jugovzhodnoalpske variante je dodal tudi negovske čelade alpske vrste $\mathrm{z}$ območja osrednjih Alp, ki imajo pasasto razširjen rob krajcev in poudarjen greben, čeprav jih je prvotno opredelil kot zahodnoalpsko inačico (Gabrovec 1950, 97-98, št. 3). tudi čelada s Kovka, njena glavna značilnost pa sta cevasti zanki za podbradni jermen na nosilcu podloge. Drugo, mlajšo je imenoval različica Idrija, zanjo sta značilni zanki ločne oblike in je v enem primeru narejena iz dveh delov. ${ }^{11}$

Čelade različice Vače je Egg na podlagi žigosanega okrasa nad vglobljenim delom oglavja in na nosilcu podloge, razdelil na dve skupini. Prvo, precej številno, ki ji je prištel 15 čelad, $z$ določeno verjetnostjo pa še 10 drugih, je opredelil kot čelade z okrasom krožnih očesc. ${ }^{12}$ Okras na oglavju je sestavljen iz kombinacij dveh nizov, od katerih je eden vedno iz krožnih očesc. Drugi niz je praviloma iz palmet, pravokotnikov ali poševnih črtkanih žigov. Nosilec podloge pa je okrašen z enim ali dvema nizoma krožnih očesc. Krožna očesca je Egg glede na obliko razdelil na štiri vrste. ${ }^{13}$

Čelade druge skupine, ki ji je prištel 9 čelad, od teh eno z zadržkom, ${ }^{14}$ je opredelil kot čelade z okrasom spiralnih očesc. Na oglavju imajo enega do tri okrasne nize, nekatere pa so na tem mestu celo brez okrasa; na nosilcu podloge imajo tako kot čelade prve skupine enega ali dva niza žigov. Prevladujoči motiv na oglavju in na nosilcu podloge

11 Egg 1986, 66-87, 218-232, sl. 179, t. 212-260; 67-68, op. 251, sl. 29; 82 .

12 Ib., 70-78, 218-226, kat. št. 298-322.

13 Ib., 68, 70, sl. 30.

14 Ib., 78-82, 226-229, kat. št. 323-331. 


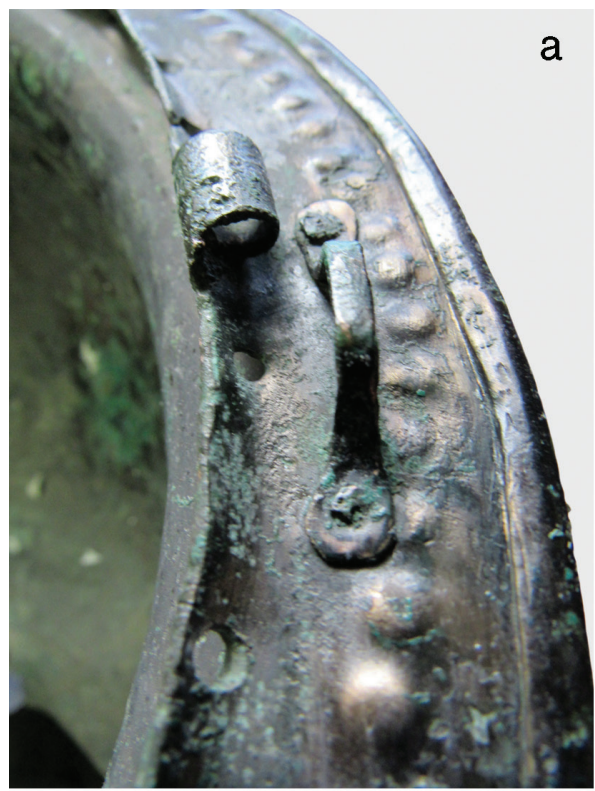

b
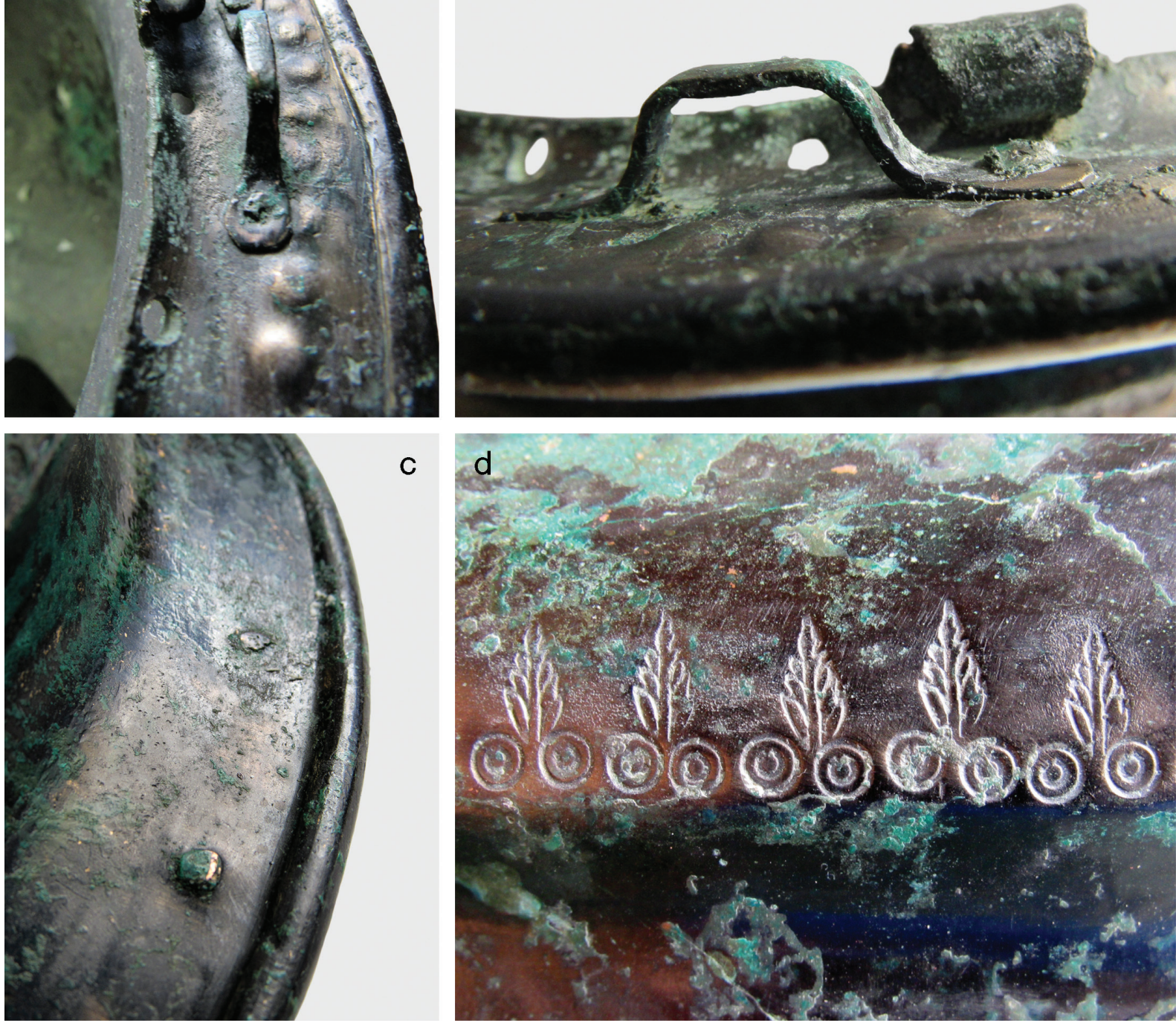

C

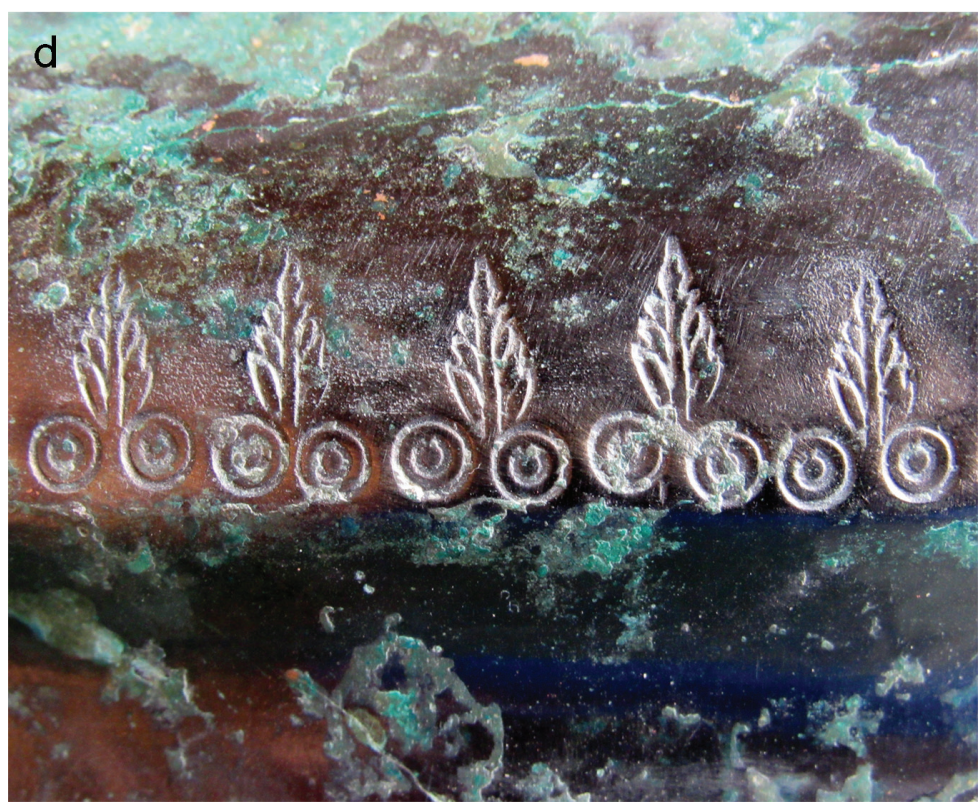

Sl. 8: Vrtača pri Kovku. Detajli negovske čelade iz groba 1. a-b - cevasta in ločna zanka na nosilcu podloge; c - zakovici ločne zanke na zgornji strani krajcev; d - okrasna niza žigov nad vglobljenim delom oglavja.

Fig. 8: Vrtača near Kovk. Details of the Negova helmet from Grave 1. a-b - tubular and trapezoid loops on the lining holder, on the underside of the brim; $c$ - rivets of the trapezoid loop on the upper side of the brim; $d$ - decorative stamped pattern above the concave part of the helmet cap.

je niz spiralnih očesc, ki ga lahko spremljajo niz palmet ali X-motivov, izjemoma pa niz pravokotnikov ali črtkanih trikotnikov. ${ }^{15}$

Čelada s Kovka sodi v prvo skupino, saj je na oglavju okrašena s kombinacijo niza dvojnih krožcev, ki jih je Egg označil kot krožna očesca druge vrste, in niza palmet $(s l .8 d)$. Enako

\footnotetext{
15 Egg 1986, 78-79, sl. 36.
}

kombinacijo najdemo kar na sedmih čeladah iz zakladne najdbe Ženjak pri Negovi. Pet jih pripada različici Vače, ${ }^{16}$ ena domnevno različici Idrija ${ }^{17}$ in

16 Ib., sl. 30: 15,17-18,20-21.

17 Ker pri tej čeladi, označeni s št. 22, nosilec podloge ni ohranjen, se je Egg pri njeni tipološki razvrstitvi oprl na okras. Zaradi domnevne enakosti žigov na tej čeladi in na čeladi različice Idrija iz Jame v Držencah (it. Grotta dell'elmo) pri Repentabru (Gherlizza, Halupca 1988, 
ena italsko-slovenski vrsti, ${ }^{18}$ ki jo je Egg opredelil kot predhodnico negovskih čelad različice Vače slovenske vrste. ${ }^{19}$

Taka kombinacija, vendar $\mathrm{z}$ dodatnim nizom iz poševnih črtkanih žigov, krasi oglavje čelade različice Vače s Kope nad Kompoljami. ${ }^{20}$ Čelade $s$ to kombinacijo okrasa so presenetljivo omejene na širše območje severno od Save (Ženjak, Kovk in Kompolje). Nasprotno se kombinacija niza krožcev s piko in niza palmet pojavlja na čeladah različice Vače na pomembnejših najdiščih dolenjske skupine južno od Save (Stična, Valična vas, Novo mesto), pa tudi na Vačah onkraj Save. ${ }^{21}$

Razlika v razprostranjenosti se kaže tudi v razmerju med številom krožnih očesc (dvojnih krožcev ali krožcev s piko) in številom palmet na čeladah, ki so okrašene s to kombinacijo. Samo na čeladah s Kovka in iz Kompolj ter dveh čeladah iz Ženjaka (št. 2 in št. 22) je krožnih očesc dvakrat toliko kot palmet ali malenkost manj, ${ }^{22}$ na vseh drugih čeladah s to kombinacijo, ki izvirajo tako iz Ženjaka kot z dolenjskih najdišč, pa je krožnih očesc toliko ali približno toliko kot palmet. ${ }^{23}$

Čelada s Kovka je na nosilcu podloge okrašena z nizom iztolčenih bunčic (sl. 8; t. 3: 1e) ${ }^{24}$ Gre za izjemo, saj imajo čelade različice Vače na nosilcih podloge žigosan okras. ${ }^{25}$

Na nosilcu podloge čelade s Kovka sta bili poleg dveh dobro ohranjenih cevastih zank, značilnih za različico Vače, skozi nosilec podloge in krajce naknadno prikovičeni dodatni ločni zanki $(s l .8 a-c$; t. 3: 1e). Enak primer poznamo samo še na eni od dveh negovskih čelad (po Eggu št. 2) iz Mecklenburške zbirke, ki sta bili pripisani grobu V/29 na

151-154; pri Eggu pod Monrupino) jo je pogojno dodelil tej različici. Pri primerjavi risb nizov palmet in nizov dvojnih krožcev na teh dveh čeladah ugotavljamo, da le ne gre za enake žige, zaradi česar uvrstitev čelade iz Ženjaka v različico Idrija ni gotova (Egg 1986, 83-84, op. 280, sl. 38: 1,6, 231, kat. št. 339, 229, kat. št. 332).

18 Egg 1986, 64, sl. 27: 3.

19 Ib., 72.

20 Ib., sl. 30: 7; Gabrovec 1965b, 101, t. 10.

${ }^{21}$ Egg 1986, 69, sl. 30: 2-5; Križ 2019, 74, sl. 52.

${ }^{22}$ Egg 1986, 64, sl. 27: 3, 218, kat. št. 297; 69, sl. 30: 7; 84, sl. 38: 6 .

23 Ib., sl. 30: 2-5,15,17-18,20-21, 225-226, kat. št. 319-321.

${ }^{24}$ Podoben okras poznamo na nosilcu podloge negovske čelade različice Idrija iz poznolatenskega groba 18 na Idriji pri Bači. Ib., 83, sl. 38: 5, 229-230, kat. št. 335, sl. 189; Guštin 1991, 17, t. 18: 1.

25 Egg 1986, sl. 30 in 36.
Magdalenski gori. ${ }^{26}$ Zakaj so na teh dveh čeladah poleg nepoškodovanih cevastih zank naknadno dodali ločni zanki, ostaja nepojasnjeno.

Ločne zanke se pojavljajo na več čeladah različice Vače kot popravilo odlomljene cevaste zanke. Ker nosilca podloge niso mogli izvleči iz krajcev, so ločno zanko prikovičili skozenj in skozi krajce. ${ }^{27}$ V nekaterih primerih (Novo mesto in Stična) se je odlomila ena cevasta zanka, ${ }^{28}$ pri drugih (čelade št. 6, 16 in 17 iz Ženjaka) pa obe. ${ }^{29}$ Pri čeladi št. 5 iz Ženjaka so prikovičili na novo kar tri ločne zanke, dve ob straneh in eno zadaj. ${ }^{30}$

\section{Pasna oprava}

Iz groba izvira veliko kovinskih delov, ki pripadajo pasni opravi. Gre za kavljasto pasno spono, ozko pravokotno ploščico, krajšo in daljšo pregibno ploščico, okove z obročkom in kratke okove. Verjetno ji lahko pripišemo tudi dva dolga okova in okroglo ploščico.

Osrednji del oprave je $26,7 \mathrm{~cm}$ dolga usločena pravokotna kavljasta pasna spona, ki ima na obeh daljših robovih kaveljčke za pritrditev na pas. $\mathrm{Na}$ strani, kjer je kavelj za zapenjanje, je spona ravno odrezana, na drugi strani se zaključuje trikotno. Izrazito sredinsko rebro prehaja na eni strani v dolg kavelj, na nasprotni pa sega na trikotni zaključek spone $(s l .9 a ; t .4: 2 \mathrm{a})$. Med rebrom in daljšima robovoma spone poteka okras široke pletenice, ki ima na vsaki strani še dva niza vtolčenih pik, med tema pa poteka valovnica $(s l .9 b)$. Okras valovnice med nizoma pik je tudi na krajših robovih spone in na trikotnem zaključku (sl. 10a; t. 4: 2a).

$\mathrm{Na}$ trikotni zaključek spone je $\mathrm{z}$ dvema zakovicama prikovičena ozka pravokotna ploščica. $\mathrm{Na}$ spono je bila pri predelavi s pomočjo sekundarno

${ }^{26}$ Ib., $68,78,82$, op. $278,226-227$, kat. št. 323 , sl. 182 , t. 241 a; Hencken 1978, sl. 137. Drugi negovski čeladi, ki je bila pripisana grobu V/29 (številka 1 po Eggu), nedvomno pripadata dva odlomka nosilca podloge, ki sta bila sicer vključena v grob V/6-7-7a z Magdalenske gore (Hencken 1978, sl. 110c; Egg 1986, 220, kat. št. 301, sl. 176). Odlomka, okrašena $\mathrm{z}$ enakimi žigi (ib., 71, Gruppe 3a, 220, kat. št. 302), se prilegata vrzelma v poškodovanem nosilcu podloge (Hencken 1978, sl. 110c in sl. 138), na kar je že pred leti opozoril Andrej Preložnik.

27 Egg 1986, 67-68, sl. 178; 180: 2; 184-185.

28 Ib., 68, 222-223, kat. št. 307, sl. 178, t. 224a; 223, kat. št. 309 , sl. 180 , t. 227 a.

${ }^{29}$ Ib., 82 , op. 278,225 , kat. št. 315 ; 227 , kat. št. 327 , sl. 184 , t. 246 a; 228 , kat. št. 328 , sl. 185.

30 Ib., 82 , op. 278,221 , kat. št. 305 , sl. 177, t. 221 a. 
a

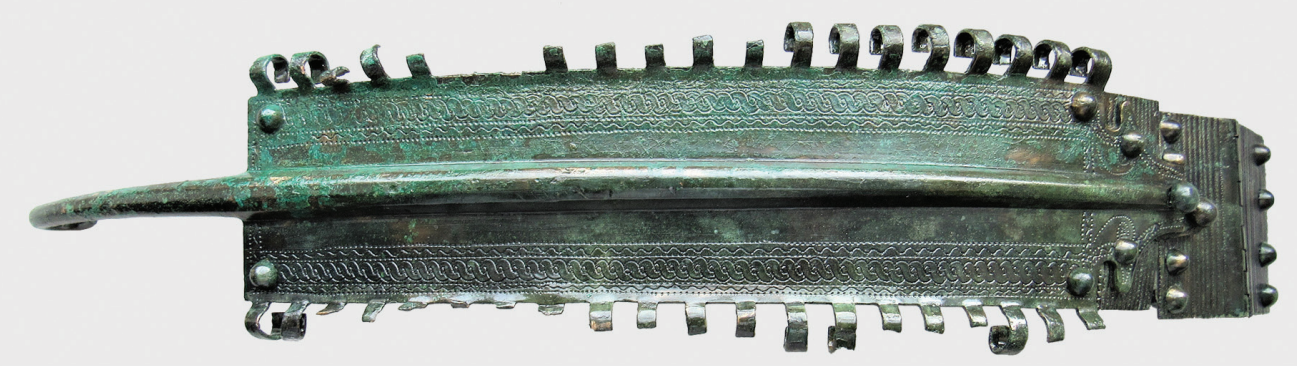

b

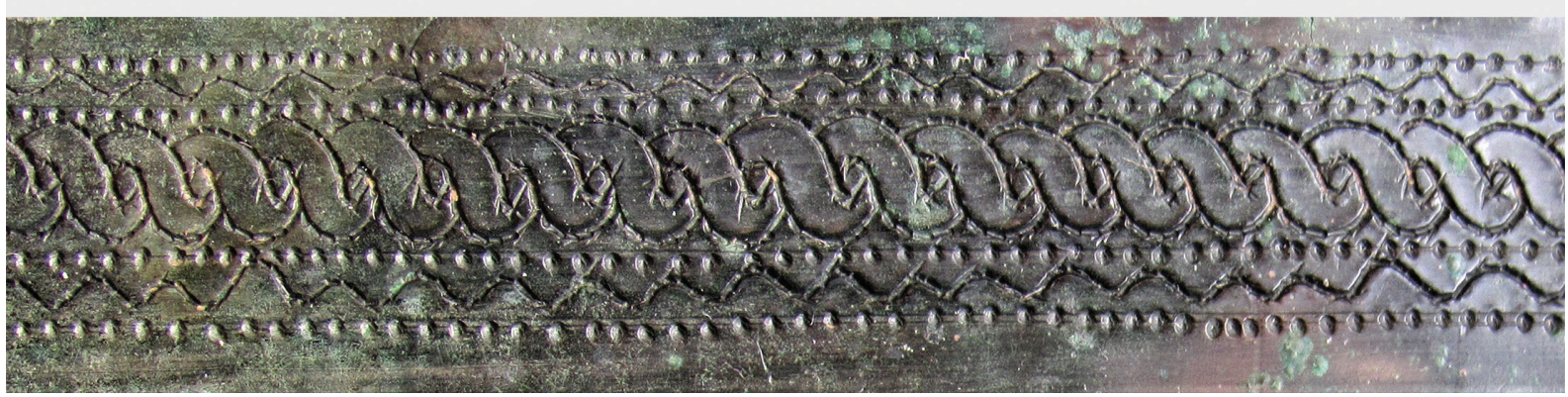

Sl. 9: Vrtača pri Kovku. a - pasna spona iz groba 1; b - detajl okrasa. M. a = 1:2.

Fig. 9: Vrtača near Kovk. a - belt plate from Grave 1; b - detail of its decoration. Scale a = 1:2.

uporabljene jezičaste ploščice in dveh zakovic pritrjena iz treh delov izdelana krajša pregibna ploščica tako, da ena zakovica povezuje jezičasto ploščico s trikotnim zaključkom spone, druga pa s pregibno ploščico (sl. 10a; t. 4: 2b-c). Jezičasta ploščica je okrašena $z$ vijugami iz vtolčenih pik. Ozka ploščica in krajša pregibna ploščica sta okrašeni z vzporednimi ozkimi žlebiči, ki so razčlenjeni. Njuna zunanja robova sta okrašena $z$ vrezi.

Tudi daljša pregibna ploščica $(t .4: 1)$ je bila sestavljena iz treh delov. En del je izdelan iz pravokotnega kosa pločevine, ki so ga prepognili in v pregibu izrezali tako, da so s pomočjo tretjega dela, vdete osi, naredili gibljivi tečaj. Ta del je enak zunanji polovici že opisane krajše pregibne ploščice. Drugi del po obliki in okrasu ustreza prvemu delu, vendar se spredaj nadaljuje $\mathrm{v}$ daljšo, v preteklosti zlomljeno ploščico, ki ima dve veliki odprtini in na koncu dva široka kaveljčka za pritrditev na pas ter je okrašena s pletenico in $\mathrm{z}$ valovnico med nizoma pik. Primerjav za take pregibne ploščice ne poznamo. Pasne spone s podobnim tečajem pa najdemo na alpskih najdiščih Caverzano, Obervintl/Vandoies di Sopra, Lothen, Steinach am Brenner. ${ }^{31}$

31 Kilian-Dirlmeier 1979, 22, sl. 2: 7; 3: 10-12; Nascimbene 1999, 91, sl. 18: 186.
K pasni opravi sodi še deset pasnih okovov, trije cevasti $\mathrm{z}$ obročkom in sedem okrog $5 \mathrm{~cm}$ dolgih žlebičastih s po dvema zakovicama, verjetno pa tudi dva ozka, $10 \mathrm{oz} .11 \mathrm{~cm}$ dolga cevasta okova, in okrogla ploščica z luknjico (t. 3: 2; 5: 1-12).

Najboljšo primerjavo za pasno opravo $s$ Kovka najdemo v že leta 1895 izkopanem grobu 1 gomile 7 iz Brezij pri Trebelnem, kjer so bili ob kavljasti pasni sponi še dva trakasta okova $z$ obročkom, en trakast okov brez obročka, dva dolga cevasta okova in dve okrogli ploščici z luknjico $(s l .11 a-d){ }^{32}$ Primerljiv ni samo sestav pasne oprave, ampak tudi posamezni elementi.

Spona iz Brezij pri Trebelnem (sl. 10b; 11a) je podobne oblike kot tista s Kovka, saj je prav tako usločena, ima sredinsko rebro, dolg kavelj, trikotni zaključek in kaveljčke na daljših robovih. Je pa nekoliko manjša in okrašena samo $z$ valovnico med dvema nizoma pik. $Z$ majhnimi vrezi sta okrašena rob spone pri kavlju in trikotni zaključek. Posebnost spone je, da ima eno samo zakovico za pritrditev na pas in da je pod njeno glavico okrogla podložka.

Zelo podobna ji je enako okrašena spona iz Ljubljanice, ki pa je ožja in je imela pet zakovic,

32 Za temeljno objavo glej Kromer 1959, 22-23, 61, t. 20; 21: 1-6. Zgolj izbor grobnega inventarja je predstavljen na sl. 11. 

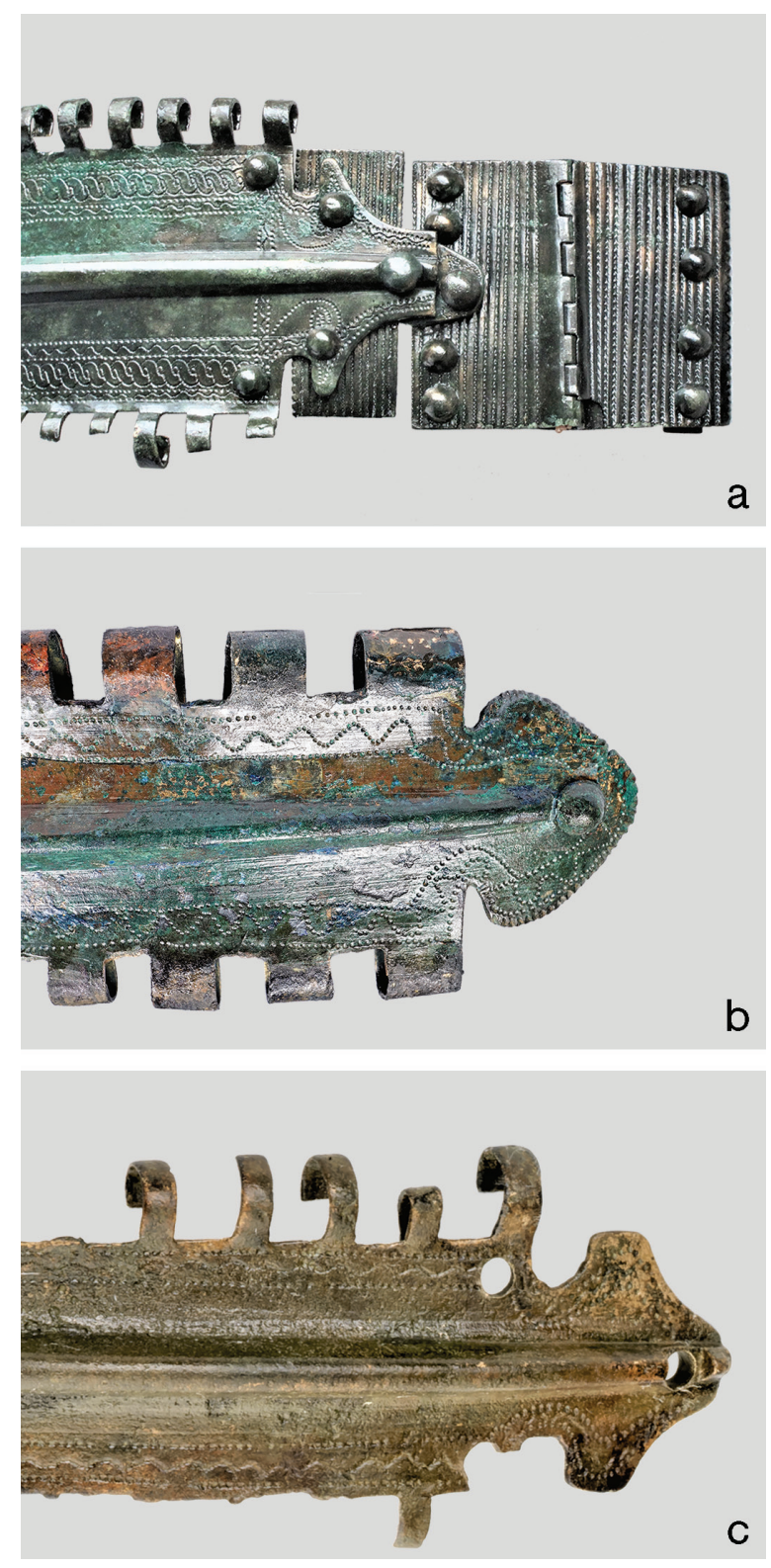

Sl. 10: Detajli kavljastih pasnih spon vrste Kovk. a - Vrtača pri Kovku, grob 1; b - Brezje pri Trebelnem, grob 7/1; c - Ljubljanica ob ledini Zaloke pri Vrhniki.

Fig. 10: Details of the Kovk type hook belt plates. a - Vrtača near Kovk, Grave 1; b - Brezje pri Trebelnem, Grave 7/1; c - the River Ljubljanica at the Zaloke site near Vrhnika.

štiri v vogalih pravokotnega dela in eno na trikotnem zaključku $(s l .10 c ; 12 a) .{ }^{33}$ Podobno pritrditev s petimi zakovicami ima tudi spona s Kovka, ki pa ima na trikotnem zaključku še dve zakovici za pritrditev ozke pravokotne ploščice (sl. 9a).

Zaradi velike podobnosti $\mathrm{v}$ obliki in okrasu je verjetno, da so bile vse tri spone izdelane na

33 Turk 2009. območju dolenjske skupine halštatske kulture. Imenujemo jih kavljaste pasne spone vrste Kovk. V okviru dolenjske skupine je obravnavanim trem sponam najbližja majhna skupina usločenih bronastih pravokotnih pasnih spon s posebej izdelanim sredinskim rebrom. Rebro na obeh straneh preide v daljši oz. krajši kavelj, nanj pa je pritrjeno tri do pet večjih obročev. Zakovice z glavico v obliki zanke, da je bil lahko vanjo vdet obroček, so pritrjevale rebro na ploščico spone. Za to skupino spon predlagamo ime kavljaste spone vrste Novo mesto. Dva primerka poznamo iz Novega mesta, ${ }^{34}$ po enega pa z Magdalenske gore, ${ }^{35}$ iz Podzemlja ${ }^{36}$ in s Kope nad Kompoljami. ${ }^{37}$ Sneža Tecco Hvala jih je datirala v mlajšo certoško in starejšo negovsko stopnjo. ${ }^{38}$

Pravokotne spone z izrazitim sredinskim rebrom in dolgim kavljem najdemo tudi na grobišču na Mostu na Soči. Ena izmed njih, najdena v grobu 1202 z izkopavanj Carla Marchesettija, ima v vogalih kaveljčke in $\mathrm{z}$ vrezi okrašen rob ob kavlju, druga iz groba $1746 \mathrm{z}$ istih izkopavanj pa ima zaključek, katerega rob je okrašen $z$ vrezi. ${ }^{39}$ Kaveljčke, narezan rob ob kavlju in zaključek $\mathrm{z}$ narezanim robom ima tudi spona iz Brezij pri Trebelnem (sl. 10b).

$\mathrm{Na}$ območju venetske kulture poznamo na najdiščih Este, Gazzo Veronese, Oppeano in Lonato pravokotne pasne spone, ki jih lahko po glavnih značilnostih (rebro, dolg kavelj, kaveljčki ob daljših robovih) primerjamo s pasnimi sponami t. i. vrste Kovk. Razlikujejo pa se po zakovicah za pritrditev na pas in po oblikovanju zaključnega roba spone, ki je večinoma ravno odrezan, $v$ primeru spone iz Oppeana pa izrazito trikoten.

Spona iz groba Randi $12 \mathrm{v}$ Este $(s l .12 b)$, ki je samo delno ohranjena, je okrašena $z$ vodoravnimi črtami in štirimi nizi tangencialno povezanih krožcev s piko. Spona iz groba Franchini $20 \mathrm{v}$ Este $(s l .12 c)^{40}$ je okrašena $\mathrm{z}$ dvema okrasnima

34 Knez 1986, t. 8: 1; 35: 1.

35 Tecco Hvala 2012, 179, sl. 69: 1.

36 Dular 1978, t. 16: 8.

37 Neobjavljeno, hrani Narodni muzej Slovenije. Za podatek se zahvaljujemo Boštjanu Laharnarju.

38 Tecco Hvala 2012, 181, op. 750.

39 Marchesetti 1993, 149, t. 26: 4; 172, t. 26: 6.

${ }^{40} \mathrm{Na}$ sponi iz Este nas je opozorila Angela Ruta Serafini iz Padove. Fotografije obeh spon in podatke o njiju nam je poslal Stefano Buson iz Museo Nazionale Atestino (Polo museale del Veneto) v Este, v katerem sta sponi shranjeni pod inv. št. IG 29784 (grob Randi 12) in IG 3346 (grob Franchini 20). Dovoljenje za objavo v tem članku je izdalo Ministero per i beni e le attività culturali e per il turismo. 
a

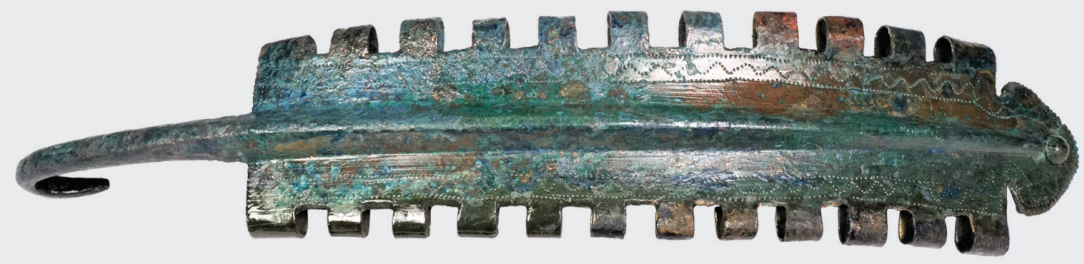

b
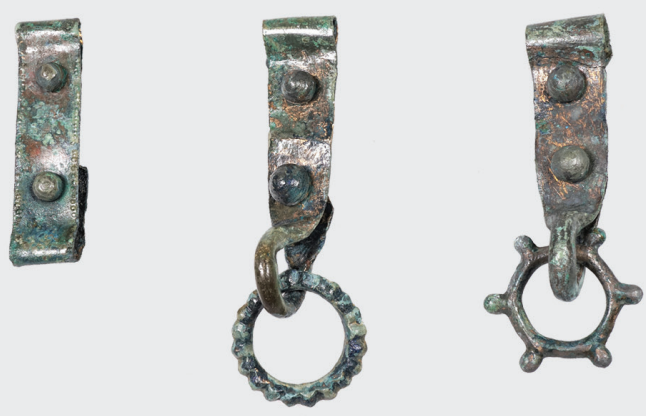

d
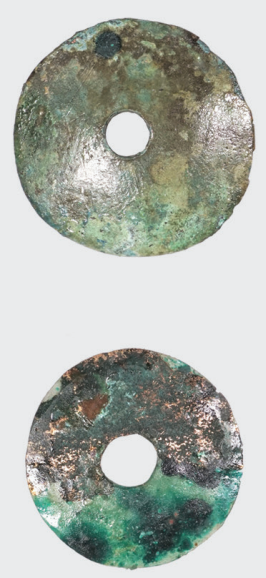

C

e

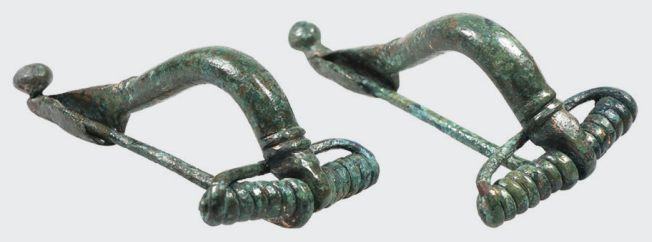

f

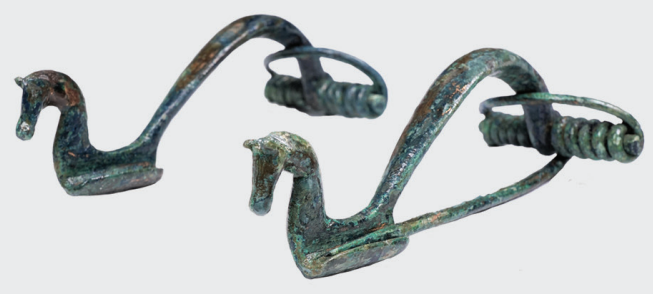

Sl. 11: Brezje pri Trebelnem, izbor kovinskih najdb iz groba 7/1. M. a = 1:2.

Fig. 11: Brezje pri Trebelnem, selection of metal goods from Grave 7/1. Scale a $=\sim 1: 2$.

pasovoma iz pletenice med dvema nizoma pik. Okras prekinjajo glavice zakovic, od katerih so samo prvi dve ob kavlju in sedmi dve prebijale pas, vse druge so okrasne. Z grobišča Dosso del Pol pri Gazzu Veronese (sl. $12 d-e$ ) poznamo spono s posebej izdelanim masivnim sredinskim rebrom, ki je z dvema zakovicama pritrjeno na pravokotno ploščo in prehaja v dolg kavelj. ${ }^{41}$ Rebro je okraše-

${ }^{41} \mathrm{Na}$ to neobjavljeno spono nas je opozoril Luciano Salzani iz Verone, ki nam je poslal tudi njeno fotografijo in opis. Hranijo jo v Centro Ambientale Archeologico Museo Civico v Legnagu (Verona). no z vzdolžnima žlebičema, med katerima je niz žigov, plošča pa s podobnimi žigi in puncirano nepravilno valovnico. Spona z najdišča Cataragna pri Lonatu $(s l .13 a)^{42}$ ni okrašena, ima pa osem zakovic; šest jih je prebijalo pas in kaveljčke. Spona z grobišča Fondo Gambin v Oppeanu ${ }^{43}(s l .13 b)$, ki je izdelana iz pločevine, ima na eni strani dolg širok kavelj, na drugi pa izrazit trikotni zaključek, katerega robova sta narezana.

\footnotetext{
42 De Marinis 1999, 555-556, sl. 24: 1.

${ }^{43}$ Salzani 1985, 82, sl. 115: 3; Salzani 2018, 154, t. 47: 2.
} 
a

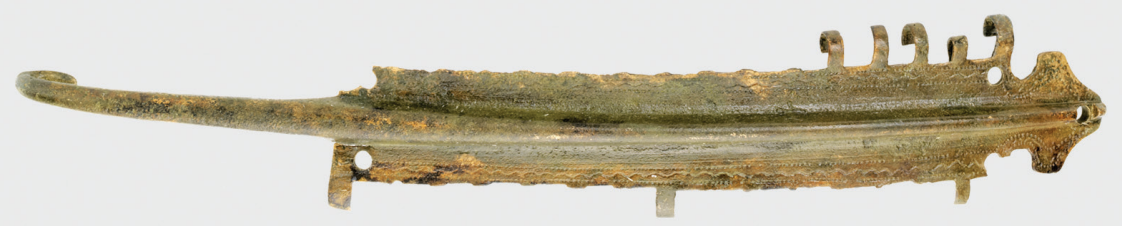

b
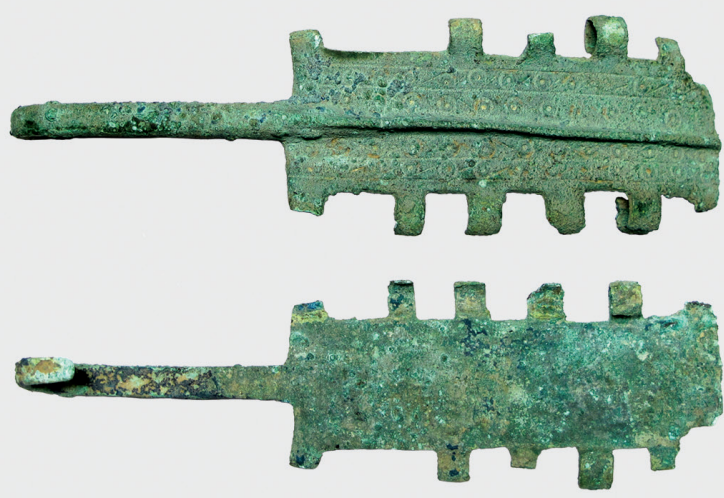

C
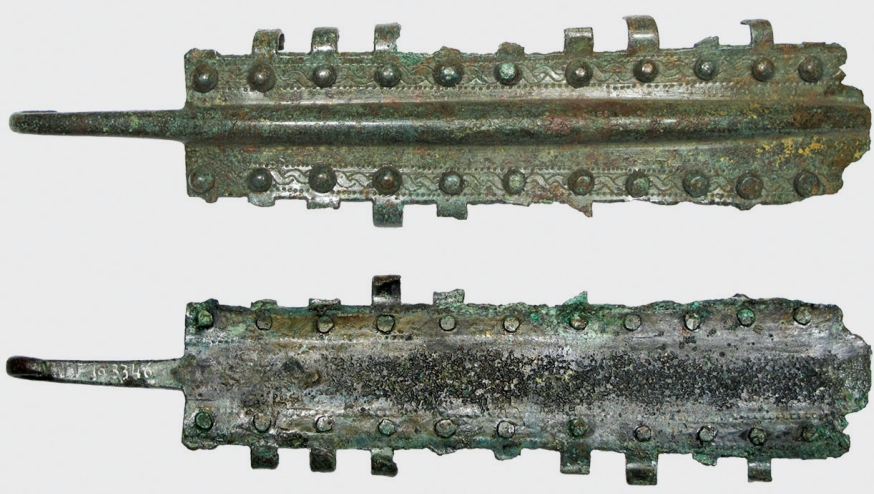

d

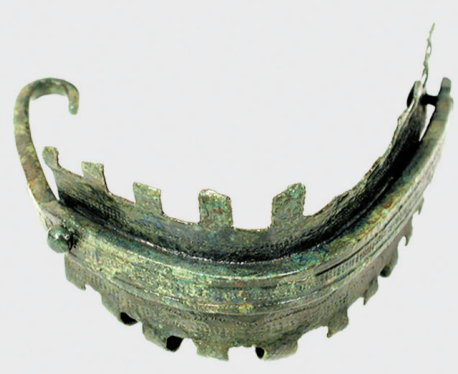

e

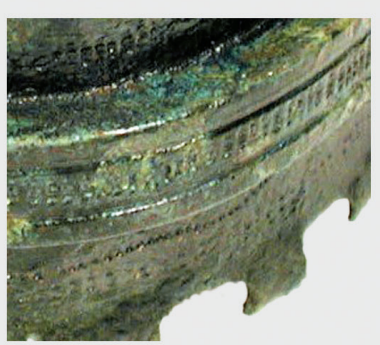

Sl. 12: Kavljasta pasna spona vrste Kovk (a) in pasne spone z dolgim kavljem in kaveljčki na daljših robovih (b-e). a - Ljubljanica ob ledini Zaloke pri Vrhniki; b - Este, Randi, grob 12; c - Este, Franchini, grob 20; d-e - Gazzo Veronese, Dosso del Pol, grob iz leta 1932. M. a-c $=\sim 1: 2$.

Fig. 12: A Kovk type hook belt plate (a) and other hook belt plates with smaller hooks along the longer sides (b-e). a - the River Ljubljanica at the Zaloke site near Vrhnika; b - Este, Randi, Grave 12; c - Este, Franchini, Grave 20; d-e - Gazzo Veronese, Dosso del Pol, grave excavated in 1932. Scale a-c $=\sim 1: 2$. 

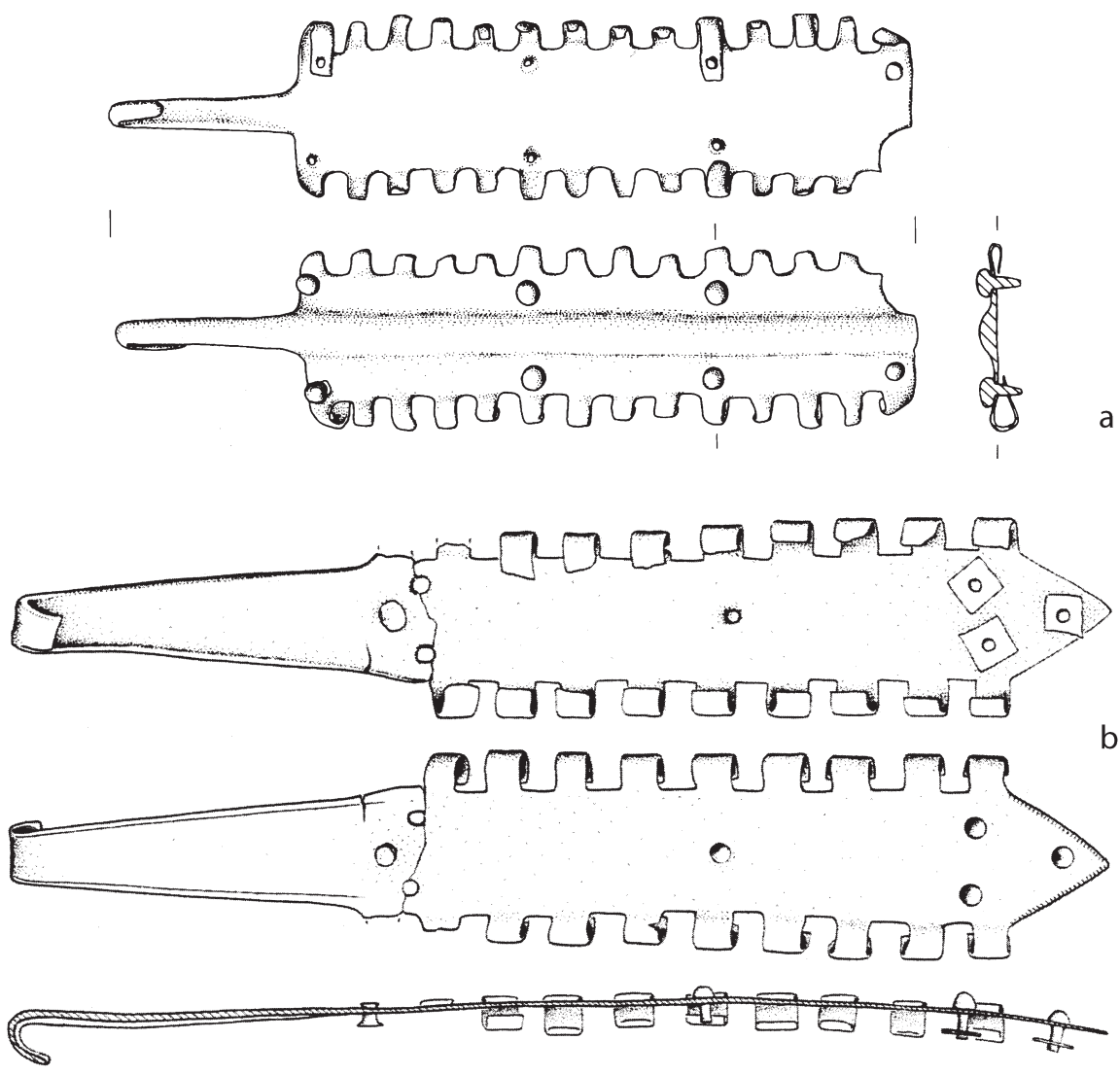

Sl. 13: Pasni sponi z dolgim kavljem in kaveljčki na daljših robovih. a - Lonato, Cataragna; b - Oppeano, Fondo Gambin, grobišče. $\mathrm{M} .=1: 2$.

Fig. 13: Hook belt plates with smaller hooks along the longer sides. a - Lonato, Cataragna; b - Oppeano, Fondo Gambin, cemetery. Scale $=1: 2$.

(Po / From De Marinis 1999 [a], Salzani 1985 [b])

Razen po splošnih značilnostih se pasne spone $\mathrm{z}$ venetskih najdišč in z Mosta na Soči povezujejo s pasnimi sponami t. i. vrste Kovk tudi v nekaterih podrobnostih. Motiv pletenice med dvema nizoma pik najdemo tako na sponi iz groba Franchini 20 v Este $(s l .12 c)$ kot na sponi s Kovka (sl. 9b). Z dolenjskimi primerki je po zaključku primerljiva spona iz groba M 1746 na Mostu na Soči. Preprost trikotni zaključek, ki ga ima spona iz Oppeana (sl. 13b), krasijo kratki vrezi, kakršne imata tudi zaključka na že omenjeni sponi z Mosta na Soči in sponi iz Brezij pri Trebelnem (sl. 10b).

Pasne spone t. i. vrste Kovk in njihove venetske primerjave prek primerkov z Mosta na Soči dobro ponazarjajo stike med severnoitalskim in jugovzhodnoalpskim prostorom (sl. 14). Pri tem po kakovosti izdelave in okrasa izstopa pasna spona s Kovka. Ta ima razen tega pregibni ploščici s tečajem, ki ima primerjave $\mathrm{v}$ osrednjem alpskem prostoru.

Tudi ostali deli pasne oprave s Kovka so vredni pozornosti. Trakasti okovi z obročkom, podobni kot tista dva iz groba 7/1 v Brezjah pri Trebelnem $(s l .11 b)$, so v dolenjski kulturni skupini sestavni del pasnih oprav s pravokotnimi pasnimi sponami. ${ }^{44}$ Nasprotno pa so cevasti okovi z obročkom izredno redki, saj primerkom s Kovka (t. 5: 1-3) kot primerjavo lahko navedemo le okov z Vač. ${ }^{45}$

Pravih primerjav za sedem kratkih žlebičastih okovov, ki imajo po dve zakovici in so ob vsaki zakovici okrašeni s po dvema snopoma prečnih vrezov in X-motivom med njima (t. 5: 4-10), ne poznamo. Podobni, a daljši okovi z enakim okrasom in $\mathrm{z}$ dvema ali več zakovicami so npr. prikovičeni vzdolž krajših stranic nekaterih pravokotnih pasnih spon dolenjske skupine, ${ }^{46}$ poznamo pa jih tudi na venetskih pasnih sponah. ${ }^{47}$

44 Prim. Tecco Hvala 2012, sl. 65-67; Tecco Hvala 2017, 111.

45 Stare 1955, t. 45: 4.

46 Tecco Hvala 2012, 178, sl. 66: 2.

47 Ib., 178, op. 738; Preložnik, Guštin 2012, 125, sl. 6; Salzani 2018, 146, 152, t. 41-42. 


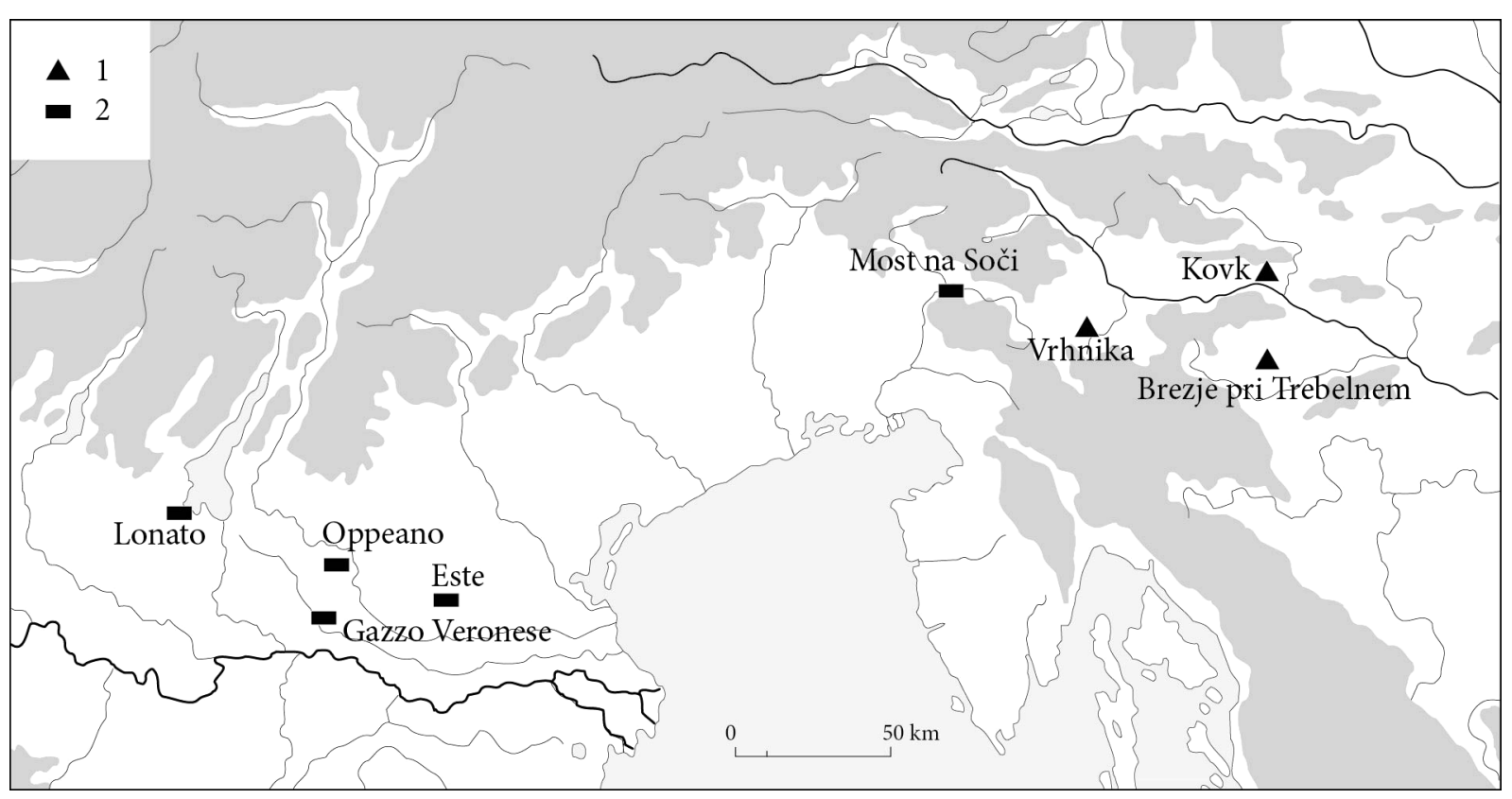

Sl. 14: Razprostranjenost kavljastih pasnih spon t. i. vrste Kovk (1) in drugih pasnih spon z dolgim kavljem in kaveljčki na daljših robovih (2).

Fig. 14: Distribution of the hook belt plates of the Kovk type (1) and other hook belt plates with smaller hooks along the longer sides (2).

Vsi opisani elementi od spone do okovov omogočajo, čeprav nimamo ohranjene situacije in situ, da lahko govorimo o posebni vrsti pasne oprave, ki jo sestavljajo kavljasta spona t. i. vrste Kovk, izjemoma dopolnjena še $z$ dvema pregibnima ploščicama, ter okovi z obročki in kratki žlebičasti okovi. Kje na pasu so bili izbočene okrogle bronaste ploščice z luknjico $\mathrm{v}$ sredini in dva dolga cevasta okova, ohranjeni tako na Kovku kot v Brezjah pri Trebelnem (t. 3: 2; 5: 11-12; sl. 11c-d), za zdaj ni mogoče ugotoviti.

Okrasni trak na pasni sponi in na daljši pregibni ploščici s Kovka, ki ima na vsaki strani pletenice po dva niza pik, med katerima poteka valovnica (sl. $9 b ;$ t. $4: 1-2)$, je pomemben element za ugotavljanje stilne pripadnosti, pa tudi za potrditev kronološkega okvirja. Motiv pletenice je sicer pogost v situlski umetnosti, ${ }^{48}$ podobno kompozicijo okrasnega traku pa najdemo na negovskih čeladah alpske vrste $\mathrm{z}$ okrasom pletenice. ${ }^{49}$

Ena sama steklena jagoda ( $t$. 3:4) v bojevniškem grobu ne preseneča, saj jo $\mathrm{v}$ moških grobovih $\mathrm{z}$ orožjem zasledimo tudi na drugih najdiščih dolenjske kulturne skupine. Po eno stekleno jagodo, $\mathrm{v}$ dveh primerih modro in $\mathrm{v}$ enem rumenorjavo,

\footnotetext{
48 Egg 1986, 101; Tecco Hvala 2012, 177.

49 Egg 1986, 102-110, sl. 51-52; na primerjavo s Kovkom je opozoril Guštin 2019, 377-378.
}

najdemo npr. v Stični v grobovih 125/22, 48/141 in 48/99, ki sodijo v stopnjo Stična 2 in v certoško stopnjo. ${ }^{50} \mathrm{Na} Z$ Znančevih njivah v Novem mestu sta vsebovala po eno modro jagodo grobova $1 / 23$ in $2 / 4,{ }^{51}$ posamezne jagode pretežno modre barve pa najdemo tudi v več bojevniških grobovih na Kapiteljski njivi v Novem mestu. Vsi novomeški grobovi sodijo v certoško ali negovsko stopnjo. ${ }^{52}$ Upravičeno smemo domnevati, da so imele posamezne steklene jagode pri bojevnikih poseben, morda apotropejski pomen.

\section{Fibula}

V grobu 1 je bila najdena razmeroma majhna noga certoške fibule ( $t .3: 3)$. Hrbet noge je ozek in neokrašen, na koncu noge pa je droben ploščat gumb. Glede na te značilnosti je zelo verjetno pripadala certoški fibuli V. vrste. ${ }^{53}$ Tovrstne fibule uvrščamo med najstarejše oblike certoških fibul, saj

\footnotetext{
50 Gabrovec 2006, t. 201: 13; 81: 7; 56: 7.

51 Knez 1986, t. 7: 8; 14: 8.

52 Križ 2019, 199: grobovi certoške stopnje 3/13, 9/6 in 60/19; grobovi negovske stopnje $2 / 29,5 / 15,7 / 1,7 / 19$, $8 / 1,14 / 26$ in $22 / 1$.

53 Teržan 1976, 323-324; Gabrovec 2006, t. 71: 2.
} 
se pojavljajo že v starejšem delu certoške stopnje, so pa v uporabi še v njenem mlajšem delu. ${ }^{54}$

Datacijo pasne oprave s Kovka nakazuje inventar groba 7/1 iz Brezij pri Trebelnem s primerljivo pasno opravo. Zaradi para certoških fibul XIII. vrste in para samostrelnih fibul z naprej gledajočo konjsko glavico $(s l .11 e-f)$ sodi grob v mlajši del certoške stopnje. ${ }^{55}$

Datacija različice Vače slovenske vrste negovskih čelad, ki ji pripada čelada s Kovka, je jasna, če se opremo na bogate bojevniške grobove $\mathrm{z}$ zanesljivo grobno celoto, kakršni so grob $4 / 3$ z Znančevih njiv v Novem mestu ter grobova $5 / 9$ in $5 / 17$ iz Dolenjskih Toplic. Gre za značilne predstavnike starejšega dela negovske stopnje, ${ }^{56} \mathrm{ki}$ jasno opredeljujejo starost čelad različice Vače, $s$ tem pa tudi čas pokopa bojevnika s Kovka.

\section{Grob 2}

Od pridatkov dekliškega groba s Kovka ( $t$. 6-7) je mogoče ožje časovno opredeliti bronasti zapestnici in nanožnici, steklene jagode trikotne oblike in železni nožiček s koščenim ročajem.

Bronasti votli zapestnici ( $t$. 6: 6-7) imata staknjena konca in sta okrašeni s snopi prečnih vrezov. Take zapestnice so bile priljubljene $\mathrm{v}$ dolenjski skupini v certoški stopnji. ${ }^{57}$

Bronasti nanožnici (t. 6:8-9) pripadata različici IIIc polnih narebrenih zapestnic in nanožnic po Sneži Tecco Hvala, ker imata stanjšana presegajoča se konca. ${ }^{58}$ Tovrstne zapestnice in nanožnice so bile standardni del ženske noše dolenjske skupine $\mathrm{v}$ stopnji kačastih fibul, $\mathrm{v}$ uporabi pa so bile še $\mathrm{v}$ certoški stopnji. ${ }^{59}$

Ogrlico iz steklenih jagod sestavlja 9 prosojnih belih, 6 prosojnih modrih, 9 rumenih s po tremi modro-belimi očesci, 1 rumena $\mathrm{z}$ valovnico in odlomek jagode prosojno rumene barve ( $t$. 6: 1-5; 7: 1-2,4-5). S svojo nepravilno trikotno obliko izstopajo rumene jagode $\mathrm{z}$ očesci $(t$. 6: 5). Med bogatim korpusom steklenega nakita dolenjske skupine poznamo podobno obliko $\mathrm{v}$ grobu $6 / 22 \mathrm{na}$

54 Dular 2003, 136; Tecco Hvala 2012, 256.

55 Prim. Dular 2003, 136, sl. 81: 8; 85: 2,4. Datacija groba iz Brezij pri Trebelnem v certoško stopnjo že v Tecco Hvala 2012, 159, op. 612; 338, op. 1423.

56 Egg 1986, 73-75, sl. 32-33; Dular 2003, 143-144, sl. $86-88$.

57 Tecco Hvala 2017, 110, op. 253.

58 Tecco Hvala 2012, 301, sl. 111: 3,6.

59 Ib., 307, op. 1305 in 1306.
Kapiteljski njivi v Novem mestu. Skupaj z dvema bronastima votlima zapestnicama in keramično posodo je bila najdena bogata ogrlica iz jantarnih in steklenih jagod, med katerimi sta dve trikotne oblike, vendar zelene barve, $\mathrm{z}$ modro-belimi očesci. ${ }^{60}$ Grob uvršča Borut Križ upravičeno v negovsko stopnjo, ${ }^{61}$ saj imajo v njem najdene steklene jagode $\mathrm{z}$ bradavičastimi izrastki zelo dobre primerjave v grobu $4 / 3$ z Znančevih njiv v Novem mestu. ${ }^{62}$

Od nožička sta ohranjena del železnega rezila in ročaj, ki ima okrašeni koščeni platici, vtaknjeni na obeh koncih v okov iz bronaste pločevine, ta je prebit $\mathrm{z}$ bronasto zakovico, na koncu ročaja pa je bronasta zanka za obešanje $(t .6: 10 ; 7: 10)$. Verjetno gre za britev s pregibnim rezilom, ki je bila predelana $\mathrm{v}$ nožiček. Za predelavo govori zakovica na platicah ročaja, ki je zagotovila negibnost rezila.

Podobne britve s pregibnim rezilom in koščenim ali roževinastim ročajem poznamo v mlajši halštatski dobi v Hallstattu, Karpatski kotlini in v dolenjski skupini. ${ }^{63}$ Več primerkov takih britev je bilo najdenih $\mathrm{v}$ moških grobovih na Magdalenski gori ${ }^{64}$ ter $\mathrm{v}$ Stični ${ }^{65}$ in v Novem mestu. ${ }^{66}$ Pojav nožička v dekliškem grobu s Kovka odstopa od pravila, saj so $\mathrm{v}$ dolenjski skupini noži različnih oblik največkrat spadali k opravam bojevnikov. ${ }^{67}$

Okras dvojnih koncentričnih krožcev s piko omogoča ožjo časovno opredelitev nožička s Kovka v negovsko stopnjo, ker se britvi s takim okrasom pojavljata $\mathrm{v}$ dveh grobovih te stopnje s Prelog na Magdalenski gori. ${ }^{68}$ Grob 2/47 sodi v negovsko stopnjo zaradi za ta čas značilne osti kopja $\mathrm{z}$ listom deltoidne oblike in rombičnega preseka, ${ }^{69}$ medtem ko grob 2/69 zaradi sekire $\mathrm{z}$ enostranskimi plavutmi in noža s ploščatim nastavkom za ročaj morda pripada celo mlajšemu delu te stopnje. ${ }^{70}$

Obročast nakit, ki ga je imela deklica, pokopana $\mathrm{v}$ tem grobu, je značilen za dolenjsko mladohalštatsko nošo, za čas pokopa $\mathrm{v}$ zgodnji negovski stopnji pa govorita nožiček in ogrlica.

${ }^{60}$ Križ, Stipančić, Škedelj Petrič 2009, 267, kat. št. 12.

${ }^{61}$ Križ 2019, 187, 195, 266.

62 Knez 1986, t. 36: 2.

63 Tecco Hvala 2012, 136-137, sl. 53: 6-7; Kozubová 2012.

64 Tecco Hvala, Dular, Kocuvan 2004, t. 36: 18; 45: 13; 58: B3.

65 Gabrovec 2006, t. 26: 20; 100: 4.

${ }^{66}$ Knez 1986, t. 4: 2.

67 Tecco Hvala 2012, 135.

68 Tecco Hvala, Dular, Kocuvan 2004, t. 45: 13; 58: B3.

69 Ib., t. 45: 14; Tecco Hvala 2012, 127, sl. 50.

70 Tecco Hvala, Dular, Kocuvan 2004, t. 58: B4,6; Tecco Hvala 2012, 118, 135-137 in 346, sl. 129. 


\section{ZAKLJUČEK}

O pomembnosti planega grobišča $\mathrm{v}$ Vrtači pri Kovku, katerega obseg je za zdaj neznan, priča bojevniški grob $1 \mathrm{z}$ negovsko čelado in izjemno pasno opravo. Vsekakor gre za grob prvaka skupnosti naselbine na Kovku. Dekle, pokopano v poleg njega ležečem grobu 2, pa je nosilo nakit, ki je $\mathrm{z}$ izjemo steklenih jagod trikotne oblike $\mathrm{v}$ dolenjski kulturni skupini povsem običajen. Grob bojevnika datiramo zaradi negovske čelade v starejši del negovske stopnje, enako pa na podlagi nožička in ogrlice tudi grob dekleta, čeprav sta oba vsebovala tudi predmete, značilne za certoško stopnjo. Uvrstitev obeh v zgodnjo negovsko stopnjo še ne pomeni, da sta bila pokojnika tudi sočasno pokopana. Čeprav skupna grobna jama ni bila jasno razpoznavna, pa bi za sočasen pokop govorili nekateri podobni primeri, znani z območja dolenjske skupine, kot sta grobova 5/17 iz Dolenjskih Toplic in 4/3 z Znančevih njiv v Novem mestu, v katerih je bila poleg bojevnika $\mathrm{z}$ negovsko čelado pokopana ženska. ${ }^{71}$

Negovska čelada opredeljuje moškega s Kovka kot pripadnika bojevniške elite. $\mathrm{V}$ nekaterih primerih (Dolenjske Toplice, Novo mesto, Libna) so bile negovske čelade slovenske in italsko-slovenske vrste tako kot na Kovku (sl. 7; t. 1-2) pred pokopom namerno obredno uničene $\mathrm{z}$ udarci bojne sekire. ${ }^{72} \mathrm{Na}$ starejših, to je dvogrebenastih čeladah, obrednih poškodb ni opaziti, so pa razen na negovskih čeladah dobro vidne tudi na obeh njim sočasnih grško-ilirskih čeladah iz groba 7/19 na Kapiteljski njivi v Novem mestu. Zato se zdi utemeljena domneva Sneže Tecco Hvala, da so se $\mathrm{v}$ negovski stopnji pojavile očitne spremembe $\mathrm{v}$ pogrebnem obredu. ${ }^{73}$ Največ tako poškodovanih čelad je bilo najdenih $\mathrm{v}$ grobovih $\mathrm{v}$ spodnji dolini Krke; čelada s Kovka v Zasavju in z dvema udarcema na oglavju poškodovana negovska čelada $\mathrm{z}$ otoka Krka v Kvarnerju pa kažeta, da je bil ta pogrebni običaj v rabi na širšem območju. ${ }^{74}$

Status bojevnika s Kovka poudarja tudi izjemna pasna oprava, ki ima najboljšo primerjavo v grobu 7/1 iz Brezij pri Trebelnem. Skupni obema opravama so kavljasta pasna spona t. i. vrste Kovk, pasni

71 Dular, Tecco Hvala 2007, 245, op. 486 in 487.

72 Egg 1986, 68; Križ 2012, 79, 122; Križ 2019, 74, sl. $52-53$.

73 Tecco Hvala 2012, 154, op. 600 in 601.

${ }^{74}$ Egg 1986, 68; Egg 1999, 325-326, 329; Blečić Kavur 2018, 737, sl. 6 . okovi z obročkom, okrogle ploščice z luknjico in po dva dolga cevasta okova. Spone t. i. vrste Kovk se skupaj z drugimi sponami z dolgim kavljem in kaveljčki na daljših robovih dobro umeščajo v kulturni koiné venetskega prostora, svetolucijske in dolenjske skupine $\mathrm{v}$ pozni halštatski dobi. Posebnost oprave s Kovka pa sta pregibni ploščici $\mathrm{s}$ tečajem, kar je pri sponah $\mathrm{z}$ dolgim kavljem in kaveljčki na daljših robovih nekaj povsem izjemnega na območju, kjer se te pojavljajo (sl. 14), medtem ko so v osrednjih Alpah dobro znane. Povezavo $\mathrm{z}$ alpskim prostorom nakazuje tudi okrasni trak, sestavljen iz široke pletenice, valovnice in nizov pik, ki krasi spono in daljšo pregibno ploščico, saj najdemo podobne kompozicije okrasa nad vglobljenim delom oglavja in na kristi negovskih čelad alpske vrste. ${ }^{75}$

Naselbina na Kovku je, kot kaže, nastala ob novi kolonizaciji Posavskega hribovja v mlajši halštatski dobi. V tem času so predvsem na območjih zahodne Dolenjske nastale številne manjše naselbine, katerih površina je znašala $\mathrm{v}$ povprečju 1,2 ha, čemur ustreza tudi situacija na Kovku. ${ }^{76}$ To novo kolonizacijo spremlja pojav planih grobišč s skeletnimi grobovi, med katera se na levem bregu Save uvrščata plana grobova s Kovka in grobišče na Cesti Borisa Kidriča v bližnjem Zagorju ob Savi. ${ }^{77}$ Gomilno grobišče pri Kovku odstopa od povedanega. Ohranjene najdbe ne zadoščajo za ugotovitev njegovega razmerja do naselbine na Kovku in planega grobišča $v$ Vrtači pod njim. O novih priseljencih na širšem območju Zagorja ob Savi pričajo tudi grobne najdbe iz Strahovelj in iz Suhega potoka pri Mediji. ${ }^{78}$

Razlogov za kolonizacijski val še ne poznamo. Očitno gre za poselitev odročnejših krajev v Posavskem hribovju. Ali je bila to samo širitev življenjskega prostora ali iskanje novih ležišč železove rude, je odprto. Morda pa so nastanku nekaterih novih naselij botrovali tudi strateški razlogi nadzora prometnih tokov tako skozi kanjon Save kot skozi lažje prehodno podolje v njegovem severnem zaledju.

75 Guštin 2019 s karto razprostranjenosti na sl. 8.

76 Dular, Tecco Hvala 2007, 143-145, sl. 82.

77 Ib., 127, op. 274, sl. 73; Draksler 2007, 149-152; glej tudi članek Murko, Draksler v tej številki Arheološkega vestnika.

${ }^{78}$ Gabrovec 1966, t. 9; 10: 2-21; Draksler 2007, 133-136. 


\section{KATALOG NAJDB}

Najdbe iz gomil na Grobišču pri Kovku hrani Narodni muzej Slovenije, najdbe iz grobov v Vrtači pri Kovku pa prazgodovinska zbirka Pokrajinskega muzeja Celje.

\section{Grobišče pri Kovku}

1. Odlomek polne bronaste drobno narebrene zapestnice D-preseka s presegajočima se stanjšanima koncema. $\mathrm{Na}$ obeh koncih je poškodovan. Rekonstruiran pr. okrog $7 \mathrm{~cm}$, največja v. 0,6 cm. Inv. št. P 12296 - (sl. 5: 1).

2. Delno ohranjen ciborij iz rdečerjavo žgane gline s črno sredico in $\mathrm{z}$ bradavicami na ramenu. Pr. dna $12,2 \mathrm{~cm}$. Inv. št. P 10499 - (sl. 5: 2).

\section{Vrtača pri Kovku}

\section{Grob 1}

1. Bronasta negovska čelada je bila vsaj sedemkrat zasekana, verjetno s sekiro. Na oglavju je tik nad vglobljenim spodnjim delom žigosan okras iz nizov dvojnih krožcev in palmet. Krožcev je dvakrat več kot palmet, ker k vsaki palmeti sodita dva krožca. Zunanji rob krajcev je zapognjen navznoter in drži obročast nosilec podloge iz pločevine, ki je okrašen $\mathrm{z}$ nizom iztolčenih bunčic. Na notranjem, navzdol zavihanem robu nosilca podloge so luknjice, namenjene pripenjanju podloge iz organske snovi, in dve cevasti zanki iz spiralno uvite pločevine za pritrditev podbradnega jermena. Blizu cevastih sta bili skozi nosilec podloge in krajce prikovičeni še dve ločni trapezasti zanki; od ene se je ohranil samo del ploščice za pritrditev; v. 19,5 cm, pr. $25-27,3 \mathrm{~cm}$. Inv. št. PR 5736 - (sl. 7-8; t. 1: 1a,b; 2: 1c,d; 3: 1e).

2. Železna tulasta sekira $\mathrm{z}$ ušescem; d. $16,3 \mathrm{~cm}$, š. $4,6 \mathrm{~cm}$. Inv. št. PR 5735 - (t. 3: 7).

3. Odlomek lista železne sulične osti; d. $4,2 \mathrm{~cm}$, š. $3,2 \mathrm{~cm}$. Inv. št. PR 5741 - (t. 3: 5).

4. Trije odlomki železnega noža; d. $11,7 \mathrm{~cm}$, š. do $1,3 \mathrm{~cm}$. Inv. št. PR 5737 - (t. 3: 6).

5. Izbočena okrogla bronasta ploščica z luknjico v sredini; v. $0,5 \mathrm{~cm}$, pr. $3,8 \mathrm{~cm}$. Inv. št. PR $5734 \mathrm{e}-(t .3: 2)$.

6. Noga bronaste certoške fibule; d. $2,6 \mathrm{~cm}, \mathrm{v} .0,8 \mathrm{~cm}$. Inv. št. PR $5740-(t .3: 3)$.

7. Jagoda iz modre steklene paste; v. $0,8 \mathrm{~cm}$, pr. $1,3 \mathrm{~cm}$. Inv. št. PR $5738-(t .3: 4)$.

8. Bronasta pasna oprava. Sestavljajo jo predmeti s kat. št. 8a-d (pravokotna pasna spona $\mathrm{z}$ dolgim kavljem [a], ozka ploščica [b], krajša pregibna ploščica [c] in daljša pregibna ploščica [d]) ter še dvanajst pasnih okovov [kat. št. 9-11].

- 8a. V enem kosu ulita pravokotna pasna spona s sredinskim rebrom, ki na eni strani prehaja v dolg kavelj, na drugi strani pa se nadaljuje na trikoten zaključek. Spona je bila s kaveljčki na zgornjem in spodnjem robu in $s$ petimi zakovicami pritrjena na pas. Štiri zakovice so v vogalih pravokotnega dela, ena pa na vrhu trikotnega zaključka, na katerem sta še dve zakovici za pritrditev ozke pravokotne ploščice. Nad rebrom in pod njim je okrašena $\mathrm{z}$ okrasnim trakom, ki ima na sredini puncirano pletenico, nad njo in pod njo pa puncirano valovnico med dvema nizoma vtolčenih pik. Okrasna trakova tvorita skupaj z motivom valovnice med nizoma pik vzdolž krajših robov pravokotnega dela pravokotnik, ki omejuje neokrašeni srednji del. Valovnica med nizoma pik je tudi ob robovih prehoda pravokotnega dela $\mathrm{v}$ trikotni zaključek in ob usločenih robovih tega zaključka. Repati spirali iz vtolčenih pik na začetku trikotnega zaključka dajeta skupaj z vijugami na gibljivi ploščici, ki povezuje trikotni zaključek s krajšo pravokotno pregibno ploščico, vtis rogate živalske glave; d. $26,7 \mathrm{~cm}$, š. $6,3 \mathrm{~cm}$. Inv. št. PR 5734 a - (sl. 9; 10a; t. 4: 2a).

- 8b. Ozka pravokotna ploščica iz pločevine je z dvema zakovicama pritrjena na trikotni zaključek in okrašena z navpičnimi ozkimi razčlenjenimi žlebiči. Levi rob je narezan. Inv. št. PR 5734 a - (sl. 10a; t. 4: 2b).

- 8c. Krajša pravokotna pregibna ploščica iz pločevine je $z$ zakovico pritrjena na sekundarno uporabljeno jezičasto gibljivo ploščico, ki ima na odlomljenem robu delno ohranjeno luknjico za zakovico in je prikovičena na ravno odrezani vrh trikotnega zaključka pasne spone. Sestavljena je iz dveh delov, povezanih s tečajem. Vsak del je izdelan iz dvojne pločevine, spete s po štirimi zakovicami, in okrašen na enak način kot ozka pravokotna ploščica. Desni rob je narezan; d. 5,4 cm, š. 4,4-4,5 cm. Inv. št. PR 5734 a - (sl. 10a; t. 4: 2c).

- 8d. Daljša pravokotna pregibna ploščica iz pločevine z dvema odprtinama ni v celoti ohranjena. Manjkajo trakovi, ki so obdajali polkrožni odprtini in so bili okrašeni z valovnico med nizoma pik. Levo od odprtin je pravokotna pregibna ploščica, ki je po obliki in okrasu zelo podobna krajši pregibni ploščici desno od pasne spone, vendar se spredaj nadaljuje najprej $\mathrm{v}$ del $\mathrm{z}$ odprtinama in nato $\mathrm{v}$ kvadratno ploščico s šestimi zakovicami in širokima kaveljčkoma za pritrditev na pas. Kvadratna ploščica je okrašena podobno kot pravokotni del pasne spone s to razliko, da imajo vsi okrasni trakovi pletenico med valovnicama in da obdajajo dve neokrašeni pravokotni polji. Inv. št. PR $5734 \mathrm{a}-\mathrm{b}-(t .4: 1 \mathrm{a}, \mathrm{b})$.

9. Trije cevasti pasni okovi iz bronaste pločevine $\mathrm{z}$ različno oblikovanim vdetim obročkom in s po tremi zakovicami s kvadratnimi podložkami, ki niso vse ohranjene. En obroček ima tri izrastke, drugi je gladek in tretji narebren. Ob zakovicah so okrašeni s štirimi snopi prečnih vrezov; d. 6,3-6,7 cm, š. 0,6-0,7 cm. Inv. št. PR 5734 c (1-3) - (t. 5: 1-3). [Sestavni deli pasne oprave kat. št. 8.] 10. Sedem kratkih žlebičastih okovov iz bronaste pločevine s po dvema zakovicama in kvadratnima ali pravokotnima podložkama, ki so ob zakovicah okrašeni s po dvema snopoma prečnih vrezov in X-motivom med snopoma; d. 4,2-4,9 cm, š. 0,6-0,7 cm. Inv. št. PR 5734 d (4-9, 11) - (t. 5: 4-10). [Sestavni deli pasne oprave kat. št. 8.] 11. Dva dolga cevasta okova iz bronaste pločevine, okrašena s po desetimi snopi po treh prečnih vrezov; d. 10,9 in $10,1 \mathrm{~cm}$, š. 0,6 in $0,5 \mathrm{~cm}$. Inv. št. PR $5734 \mathrm{~d}(2,3)-(t$. 5: 11-12). [Sestavna dela pasne oprave kat. št. 8.] 
12. Odlomek bronaste igle; d. $4,6 \mathrm{~cm}$, pr. $0,3 \mathrm{~cm}$. Inv. št. PR $5734 \mathrm{~d}(1)-(t .5: 13)$.

13. Bronasta zakovica; d. $0,7 \mathrm{~cm}$, pr. $0,6 \mathrm{~cm}$. Inv. št. $P R$ $5734 \mathrm{~d}(10)-(t .5: 14)$.

14. Trije usločeni trakasti odlomki iz tanke bronaste pločevine; d. 0,6-0,9 cm, š. 0,4-0,5 cm. Inv. št. PR 5734 a $(2,3,1)-($ t. 5: 15-17)

15. Trije odlomki dveh kvadratnih podložk in odlomek pravokotne podložke $\mathrm{z}$ delno ohranjenima luknjicama; d. $0,5-0,8 \mathrm{~cm}$, š. $0,3-0,4 \mathrm{~cm}$, d. $1,4 \mathrm{~cm}$, š. $0,8 \mathrm{~cm}$. Inv. št. PR $5734 \mathrm{~d}(13,12)$ in PR 5739 - (t. 5: 18-20).

\section{Grob 2}

1. Osem prosojnih belih in ena motno bela steklena jagoda; pr. $0,6-0,9 \mathrm{~cm}$, deb. $0,25-0,5 \mathrm{~cm}$. Inv. št. PR 5754-5756, $5758,5759,5766-5769-(t .6: 1 ; 7: 1)$.

2. Šest prosojnih modrih steklenih jagod; pr. 0,8-0,9 cm, deb. 0,3-0,55 cm. Inv. št. PR 5747-5750, 5757, $5771-$ (t. 6: $2 ; 7: 2)$.

3. Odlomek prosojne rumene steklene jagode; pr. $0,8 \mathrm{~cm}$, deb. 0,4 cm. Inv. št. PR 5773 - (t. 6: 3).

4. Motno rumena steklena jagoda $\mathrm{z}$ valovnico, ki je izpadla; pr. $1,3 \mathrm{~cm}$, deb. $0,9 \mathrm{~cm}$. Inv. št. PR $5742-(t .6: 4 ; 7: 4)$.

5. Devet rumenih steklenih jagod nepravilne trikotne oblike s po tremi modro-belimi očesci; pr. $0,9 \mathrm{~cm}$, deb. 0,3-0,5 cm. Inv. št. PR 5743-5746, 5751-5753, 5770, $5772-(t .6: 5 ; 7: 5)$.

6. Votli zapestnici iz bronaste pločevine s staknjenima koncema sta okrašeni s širokimi snopi prečnih vrezov; pr. $6,8 \mathrm{~cm}, 6,9 \mathrm{~cm}$, deb. $0,7 \mathrm{~cm}, 0,75 \mathrm{~cm}$. Inv. št. PR $5760,5761-(t .6: 6-7 ; 7: 6-7)$.

7. Polni bronasti narebreni nanožnici s presegajočima se stanjšanima koncema; pr. 9,4 cm, deb. 0,5 cm. Inv. št. PR 5763, 5764 - (t. 6: 8-9; 7: 8-9).

BLEČIĆ KAVUR, M. 2018, Ritualiziranje kaciga - simboličan protokol željeznog doba Dolenjske (Ritualizing Helmets - Symbolic Protocol of the Iron Age in Dolenjska). Etnoantropološki problemi 13/3, 730-745.

BOLTA, L. 1975, s. v. Kovk, Krnice, Zagorice. - V: Arheološka najdišča Slovenije, 263-264, Ljubljana.

DE MARINIS, R. C. 1999, Il confine occidentale del mondo proto-veneto / paleo-veneto dal Bronzo finale alle invasioni galliche del 388 a.C. - V: Protostoria e storia del "Venetorum angulus". Atti del XX convegno di studi etruschi ed italici, 511-564, Pisa, Roma.

DRAKSLER, M. 2007, Območje Zagorja ob Savi v prazgodovini (Das Gebiet von Zagorje ob Savi in der Vorgeschichte). - Arheološki vestnik 58, 121-155.

DULAR, J. 1978, Podzemelj. Katalog najdb (Katalog der Funde). - Katalogi in monografije 16.

DULAR, J. 2003, Halštatske nekropole Dolenjske (Die hallstattzeitlichen Nekropolen in Dolenjsko). - Opera Instituti Archaeologici Sloveniae 6.

DULAR, J., S. TECCO HVALA 2007, South-Eastern Slovenia in the Early Iron Age / Jugovzhodna Slovenija v starejši železni dobi. - Opera Instituti Archaeologici Sloveniae 12.
8. Nožiček z železnim rezilom in z ročajem iz dveh koščenih platic, ki sta na vsakem koncu vtaknjeni v okov iz bronaste pločevine, prebit z bronasto zakovico. Ena platica je okrašena s tremi dvojnimi krožci s piko, na drugi je viden en krožec s piko. Nožiček je bil predelan iz britve s pregibnim rezilom. Pri predelavi so verjetno prvotno rezilo zamenjali $\mathrm{z}$ rezilom s ploščatim nastavkom za ročaj, ki so ga dodatno pritrdili z bronasto zakovico tik za sprednjim okovom. Na ročaju je pred tremi krožnimi očesci luknjica brez sledov kovine, na njegovem koncu pa je bronasto ušesce za obešanje; $d$. $11,8 \mathrm{~cm}$, š. $1,6 \mathrm{~cm}$. Inv. št. PR 5762 - (t. 6: 10; 7: 10).

9. Odlomki dna sklede sivorjave barve iz grobozrnate gline; pr. dna $11,5 \mathrm{~cm}$, v. $4 \mathrm{~cm}$. Inv. št. PR $5774-(t .6: 11)$.

10. Odlomek dna posode sivorjave barve iz grobozrnate gline; d. 4,4 cm, v. 2 cm. Inv. št. PR 5765 - (t. 6: 12).

\section{Zahvala}

Avtorji se za sodelovanje in posredovane podatke zahvaljujemo članom terenske ekipe PM Celje Maji Bausovac, Juretu Krajšku, Nini Sovdat, Faruku Pašiću, Matjažu Erneclu in konservatorki Nadi Šmid, antropologinji Zdravki Hincak s Filozofske fakultete v Zagrebu, Dragu Omanu iz Maribora, ki je narisal vse najdbe iz grobov v Vrtači, Poloni Bitenc in Petru Turku iz Narodnega muzeja Slovenije v Ljubljani, Petri Stipančić iz Dolenjskega muzeja v Novem mestu, Angeli Ruta Serafini iz Padove, Stefanu Busonu iz Este, Lucianu Salzaniju iz Verone, Sneži Tecco Hvala, Mateji Belak, Tamari Korošec in Dragu Valohu z Inštituta za arheologijo ZRC SAZU ter še posebej za kolegialno pomoč Mitju Guštinu iz Ljubljane.

EGG, M. 1986, Italische Helme. Studien zu den ältereisenzeitlichen Helmen Italiens und der Alpen. - RömischGermanisches Zentralmuseum / Monographien 11.

EGG, M. 1999, Waffenbrüder? Eine ungewöhnliche Bestattung der Frühlatènezeit in Novo mesto in Slowenien. - Jahrbuch des Römisch-Germanischen Zentralmuseums Mainz 46/2, 317-356.

GABROVEC, S. 1950, Dve novi najdbi čelad s slovenskega ozemlja (Two New Finds of Helmets on the Slovene Territory). - Arheološki vestnik 1, 87-112.

GABROVEC, S. 1965a, Kronologija čelad negovskega tipa. - V: Arheološke študije 2, Situla 8, 177-186.

GABROVEC, S. 1965b, Kamniško ozemlje v prazgodovini. - Kamniški zbornik 10, 89-134.

GABROVEC, S. 1966, Zagorje v prazgodovini (Zagorje in der Vorgeschichte). - Arheološki vestnik 17, 19-49.

GABROVEC, S. 2006, Stična 2/1. Gomile starejše železne dobe / Grabhügel aus der älteren Eisenzeit. Katalog. Katalogi in monografije 37.

GHERLIZZA, F., E. HALUPCA 1988, Spelaeus. Monografia delle grotte e dei ripari sottoroccia del Carso triestino nelle quali sono stati rinvenuti resti di interesse archeologico. - Trieste. 
GUŠTIN, M. 1991, Posočje. Posočje in der jüngeren Eisenzeit (Posočje v mlajši železni dobi). - Katalogi in monografije 27.

GUŠTIN, M. 2019, Zu den alpinen Negauer Helmen aus Reutte (Tirol) und Nesactium (Istrien). Mit einem Beitrag von Kristina Mihovilić. - V: H. Baitinger, M. Schönfelder (ur.), Hallstatt und Italien. Festschrift für Markus Egg, Römisch-Germanisches Zentralmuseum / Monographien 154, 365-388.

HENCKEN, H. 1978, The Iron Age Cemetery of Magdalenska gora in Slovenia. - American School of Prehistoric Research / Bulletin 32.

HOFBAUER, L. 1955, Iz Hrastnika. - Zasavski tednik 8, št. 23, 11. 6. 1955, 7.

KILIAN-DIRLMEIER, I. 1979, Hallstattzeitliche Gürtelbleche aus Tirol. - Bayerische Vorgeschichtsblätter 44, 13-25.

KNEZ, T. 1986, Novo mesto 1. Halštatski grobovi / Hallstattzeitliche Gräber. - Carniola Archaeologica 1.

KOZUBOVÁ, A. 2012, Vreckový nožík alebo britva? K interpretácii niektorých predmetov z kosti a parohoviny z pohrebísk vekerzugskej kultúry (Ein Taschen- oder ein Rasiermesser? Zur Interpretation einiger Knochen- und Geweihgegenstände aus Gräberfeldern der Vekerzug-Kultur). - Zborník Slovenského národného múzea. Archeológia 22, 59-77.

KRIŽ, B. 2012, Odsevi prazgodovine v bronu. Situlska umetnost Novega mesta / Reflections of Prehistory in Bronze. The Situla Art of Novo mesto. - Novo mesto.

KRIŽ, B. 2019, Kapiteljska njiva. Način pokopa v starejši železni dobi (Burial rite in the Early Iron Age). - Carniola Archaeologica 8.

KRIŽ, B., P. STIPANČIĆ, A. ŠKEDELJ PETRIČ 2009, Arheološka podoba Dolenjske / The Archaeological Image of Dolenjska. - Novo mesto.
KROMER, K. 1959, Brezje. Halštatske gomile z Brezij pri Trebelnem / Hallstättische Hügelgräber aus Brezje bei Trebelno. - Arheološki katalogi Slovenije 2.

MARCHESETTI, C. 1993 (reprint), Scritti sulla necropoli di S. Lucia di Tolmino (scavi 1884-1902). - Trieste.

NASCIMBENE, A. 1999, Caverzano di Belluno. Aspetti e problemi di un centro dell'età del Ferro nella media valle del Piave. - Trieste.

PRELOŽNIK, A., M. GUŠTIN 2012, Cinturoni da parata: esempi di contatti tra l'area veneta e la Dolenjska nell'età del ferro. - V: Giulia Fogolari e il suo "repertorio ... prediletto e gustosissimo". Aspetti di cultura figurativa nel Veneto antico, Archeologia Veneta 35, 118-127.

SALZANI, L. 1985, Preistoria e Protostoria nella media pianura veronese. - Oppeano.

SALZANI, L. 2018, Necropoli dei Veneti antichi a Ca' del Ferro di Oppeano (Verona). - Documenti di Archeologia 60.

SARIA, B. 1937, Novi napisi (Neue Inschriften). - Glasnik Muzejskega društva za Slovenijo 18, 132-135.

STARE, F. 1955, Vače. - Arheološki katalogi Slovenije 1.

TECCO HVALA, S. 2012, Magdalenska gora. Družbena struktura in grobni rituali železnodobne skupnosti / Social structure and burial rites of the Iron Age community. Opera Instituti Archaeologici Sloveniae 26.

TECCO HVALA, S. 2017, Molnik pri Ljubljani v železni dobi / The Iron Age site at Molnik near Ljubljana. - Opera Instituti Archaeologici Sloveniae 36.

TECCO HVALA, S., J. DULAR, E. KOCUVAN 2004, Železnodobne gomile na Magdalenski gori (Eisenzeitliche Grabhügel auf der Magdalenska gora). - Katalogi in monografije 36.

TERŽAN, B. 1976, Certoška fibula (Die Certosafibel). Arheološki vestnik 27, 317-536.

TURK, P. 2009, Kavljasta pasna spona. - V: P. Turk et al. (ur.), Ljubljanica - kulturna dediščina reke, 218-219, kat. št. 27, Ljubljana.

\title{
Late Hallstatt burials from Kovk above Hrastnik, in the Zasavje region (central Slovenia)
}

\author{
Summary
}

The chance finds that came to light in 2015 at Vrtača, below the summit of the Kovk hill above Hrastnik, consisted of a Negova helmet, an exceptional belt set and a socketed axe. The artefacts were acquired by the Pokrajinski muzej Celje. Presuming they were the goods of a warrior grave, it surveyed the site and its vicinity already in February 2016 and established the remains of an Iron Age settlement on the summit of Kovk (659 $\mathrm{m}$ asl). The settlement is elongated oval in plan, measures roughly $460 \mathrm{~m}$ in circumference and covers a surface of ca 0.9 ha (Figs. 1-3).

In addition to the survey, the museum also conducted trial trenching between August and October 2016 to examine the reported findspot and the hillfort above it. Trench 2, located on the south edge of the settlement terrace, revealed a 50-60 cm wide drywall with flat faces of large stones and a rubble core (Fig. 4). Trench 3 sought to investigate the continuation of the same wall, 
but only revealed a large quantity of stones. Both trenches yielded sherds of Early Iron Age pottery.

Trench 1 (Fig. 6) investigated the findspot at Vrtača and revealed the skeleton of a man with the goods previously left buried (Grave 1) and next to it the skeleton of a girl with her jewellery (Grave 2). The loamy fill of the grave pit was undistinguishable from the surrounding ground, hence its outline could not be identified and it was not possible to establish whether we are dealing with a single double burial or with two burials in separate pits.

The skeleton in Grave 1 lay in greasy grey loam. It was oriented north-south with a slight westward deviation and the head in the north (Fig. 6). Adding to the goods found by chance in 2015 , excavations revealed a blade fragment of a spearhead, the foot of a Certosa fibula, a small knife, a blue glass bead and additional parts of the belt set. The remains of the belt were found in the upper leg area under the traces of the helmet lining. The deceased buried with such rich goods (Figs. 7-9; Pls. 1-5) was an estimated 25-30 years (closer to 30) old and 169 $\mathrm{cm}$ tall. The anthropological analysis also observed pathological changes on the skeleton consisting of porotic hyperostosis and periostitis.

The skeleton in Grave 2 was placed parallel with that in Grave 1 (Fig. 6). The grave goods consist of 26 multi-coloured glass beads, two hollow bracelets, two solid ribbed anklets and a razor transformed into a small knife (Pls. 6-7). The girl was an estimated 13-15 years old and $135 \mathrm{~cm}$ tall. A fragment of the left tibia shows porotic hyperostosis.

The extent of the cemetery is unknown, but its significance is clear from the warrior grave with a Negova helmet and exceptional belt. This is certainly the burial of a prince of the community living in the settlement on Kovk. The Negova helmet shows that the burial took place in the early Negova phase. The same chronological attribution can be proposed for the burial of the girl, on the basis of the small knife and necklace, though both graves also contained items typical of the previous, Certosa phase. In spite of the common chronological attribution the two deceased may not have been buried simultaneously, given that the edges of the grave pit could not be clearly traced. However, there are examples in Dolenjska (Graves 5/17 from Dolenjske Toplice and $4 / 3$ from Znančeve njive in Novo mesto) where a woman was buried next to a warrior with a Negova helmet.
The helmet from Kovk (Figs. 7-8; Pls. 1-2; 3: 1e) with damaged cap is one of a group of Negova helmets (Dolenjske Toplice, Novo mesto, Libna, the Krk island) intentionally damaged with a battle axe as part of the burial ritual. Typologically, it is the Vače variant of the Slovenian type of Negova helmets. It bears stamped decoration above the concave part of the cap composed of a line of double rings, one of the four forms of Kreisaugen according to Markus Egg, below and a line of palmettes above (Fig. $8 d$ ). This shows it is one of a large group of helmets of this variant decorated with Kreisaugen on the cap and on the lining holder (Futterblech) on the underside of the brim; on the cap, this pattern occurs in combination with other patterns such as palmettes or rectangles. The relatively rare combination of a line of double rings and a line of palmettes, as well as the higher (double) number of Kreisaugen with regards to palmettes tie the helmet from Kovk with helmets in the wider area north of the River Sava, i.e. with some of the Negova helmets from Ženjak near Negova and with the example from Kompolje near Lukovica. In contrast, the helmet from Kovk bears a line of bosses on the lining holder (Fig. $8 a-b)$ in which it differs from all other helmets with Kreisaugen decoration of the Vače variant that have mostly one and in some cases two lines of Kreisaugen in this part.

The high status of the deceased warrior from Kovk is underscored by the remains of an exceptional belt (Fig. 9; Pls. 3: 2; 4-5). It consists of the hook belt plate, two hinged rectangular plates, fittings with and without a loop and ring, pair of tubular fittings, likely also perforated disc. The closest parallel comes from slightly earlier Grave 7/1 from Brezje pri Trebelnem (Fig. 11). The two belts share the hook plate of the Kovk type, fittings with a loop and ring, perforated discs and a pair of tubular fittings. The Kovk type belt plates are elongated rectangles with a triangular terminal at one end and a long hook at the other that continues as a pronounced rib along the centre of the plate, while both longer edges bear small hooks with which the plate was attached to the organic strap. Three examples of this type are known thus far (Kovk, Brezje pri Trebelnem and the River Ljubljanica at Vrhnika - Figs. 9-10; 11a; 12a). Together with similar belt plates from Most na Soči and several sites in Veneto and eastern Lombardy (Figs. 12b-d; 13), they are an expression of the Late Hallstatt cultural koiné spanning from the Venetic culture across the Sveta Lucija to the Dolenjska group (Fig. 14). 
The belt remains from Kovk also stand apart in that they include two hinged rectangular plates (Fig. 10a; Pl. 4: 1,2c), placed on either side of the hook belt plate; this is unknown on other belt plates with a long hook and small hooks along the longer edges (Fig. 14), but common on the belt plates from the central Alps. The decoration of a guilloche flanked by a wavy line and lines of dots on the belt plate and on the longer hinged plate support a connection with the central Alpine area (Fig. 9; Pl. 4: 1b,2a), where similar patterns occur above the concave parts of caps and on crests of the Alpine type Negova helmets.

It would appear that the settlement on the Kovk hill was established as part of the new colonisation in the hills of the Posavsko hribovje in the Late Hallstatt period. Numerous smaller settlements appeared at this time, primarily in western Dolenjska, measuring on average 1.2 ha in size; the settlement on Kovk corresponds well with this picture. The new colonisation is accompanied by new flat cemeteries with inhumation burials. North of the Sava, these comprise the flat cemeteries below Kovk and at the Cesta Borisa Kidriča site in nearby Zagorje ob Savi. The area of the Kovk village also holds a tumulus cemetery, but the surviving finds (Fig. 5) are insufficient to establish its relationship to the settlement on the summit of the Kovk hill and to the flat cemetery at Vrtača below the summit. Evidence of new immigrants in the wider area of Zagorje ob Savi also comes in the shape of grave goods from Strahovlje and Suhi potok near Medija.

The reasons behind this new colonisation in the remote areas of the Posavsko hribovje are unclear.
It may be the result of an expanding living space of the Dolenjska Hallstatt community or prospection and exploitation of new iron ore deposits. It is also possible that some of the new settlements had a strategic component and were established to more effectively control the communication lines through the gorge of the Sava in this stretch and through the valleys to the north.

Translation: Andreja Maver

\author{
Dragan Božič \\ Znanstvenoraziskovalni center SAZU \\ Inštitut za arheologijo \\ Novi trg 2 \\ SI-1000 Ljubljana \\ dragan.bozic@zrc-sazu.si \\ https://orcid.org/0000-0002-4240-3700 \\ Andrej Gaspari \\ Univerza v Ljubljani \\ Filozofska fakulteta \\ Oddelek za arheologijo \\ Zavetiška 5 \\ SI-1000 Ljubljana \\ andrej.gaspari@ff.uni-lj.si \\ Darja Pirkmajer \\ Klanc 78 \\ 3204 Dobrna \\ darja.pirkmajer@gmail.com
}

Slikovno gradivo: sl. 4 (foto: Nina Sovdat, PM Celje). - Sl. 7-9; t. 7 (foto: Nada Šmid, PM Celje). - Sl. 10a (foto: Mitja Guštin). - Sl. 10b; 11 (foto: Maciej Karwowski). - Sl. 10c; 12a (foto: Tomaž Lauko, NMS). - Sl. 12b,c (foto: Stefano Buson, MN Atestino). - T. 1-6 (risba: Drago Oman, PM Maribor).

Illustrations: Fig. 4 (photo: Nina Sovdat, PM Celje). - Figs. 7-9; Pl. 7 (photo: Nada Šmid, PM Celje). - Fig. 10a (photo: Mitja Guštin). - Figs. 10b, 11 (photo: Maciej Karwowski). - Figs. 10c; 12a (photo: Tomaž Lauko, NMS). - Figs. 12b,c (photo: Stefano Buson, MN Atestino). - Pls. 1-6 (drawing: Drago Oman, PM Maribor). 
Poznohalštatska grobova s Kovka nad Hrastnikom v Zasavju

521

Gr. 1

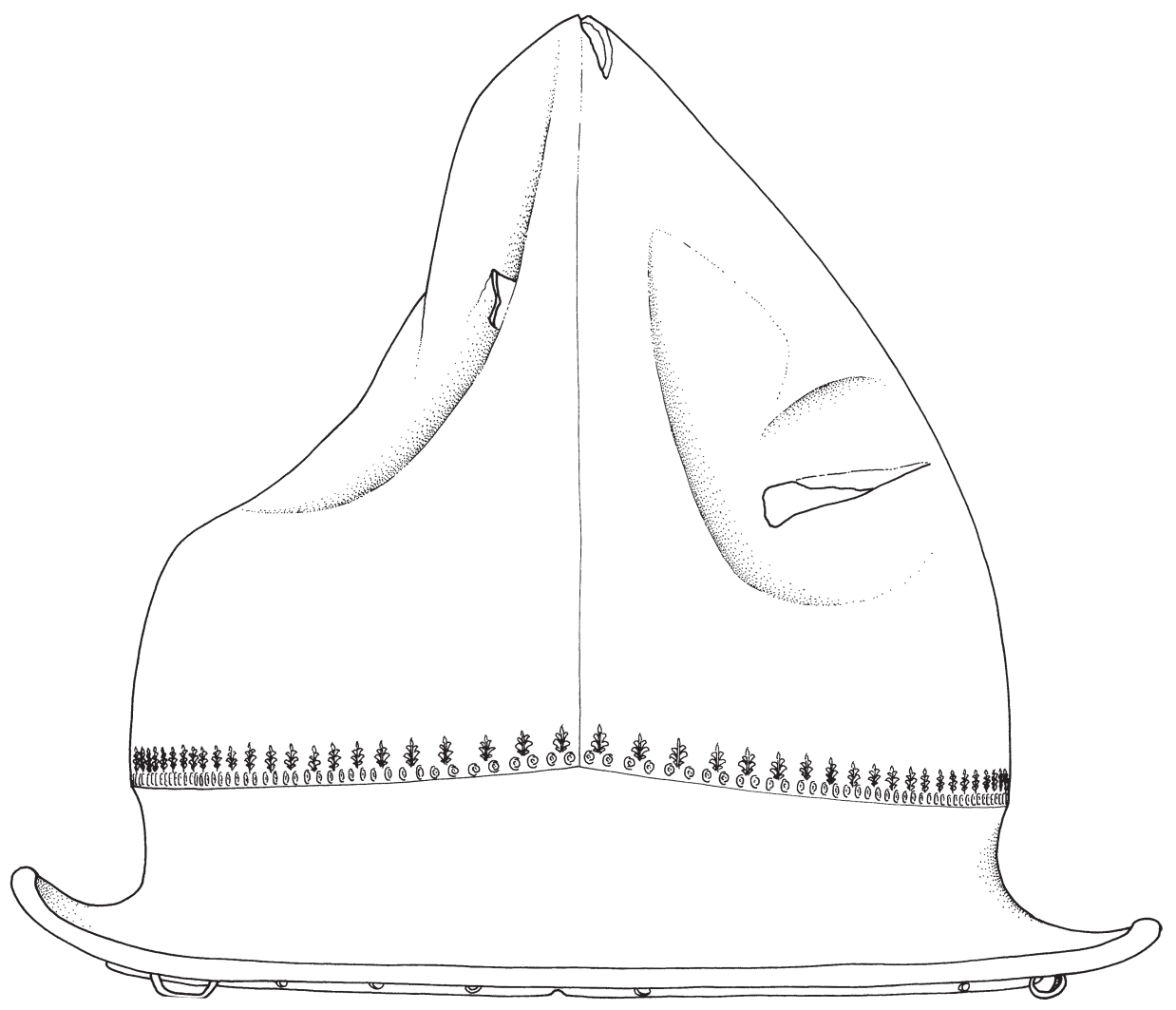

$1 \mathrm{a}$

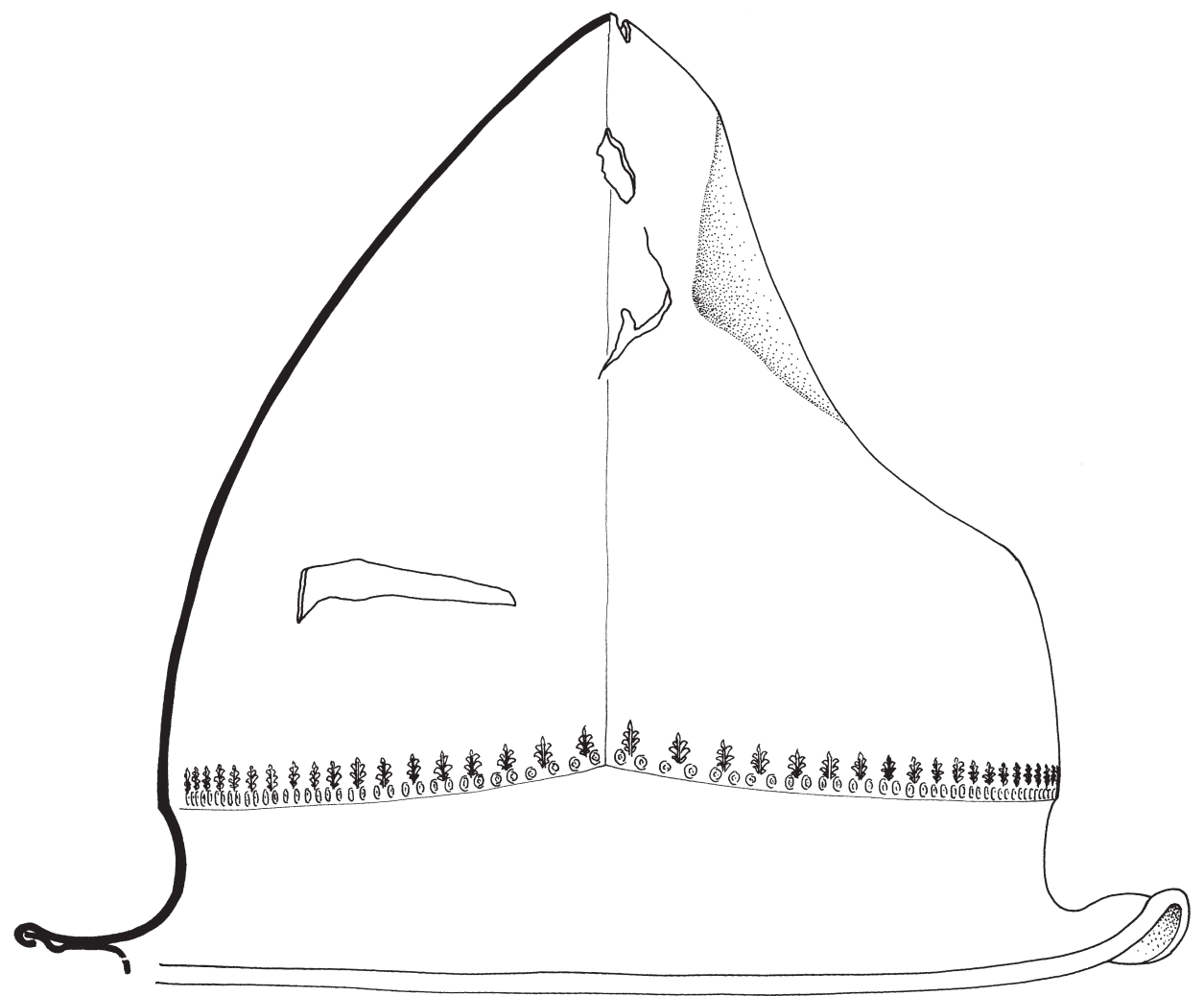

$1 b$

T. 1: Vrtača pri Kovku, grob 1. Bron. M. = 1:2.

Pl. 1: Vrtača near Kovk, Grave 1. Bronze. Scale $=1: 2$. 
522

Dragan BOŽIČ, Andrej GASPARI, Darja PIRKMAJER

Gr. 1

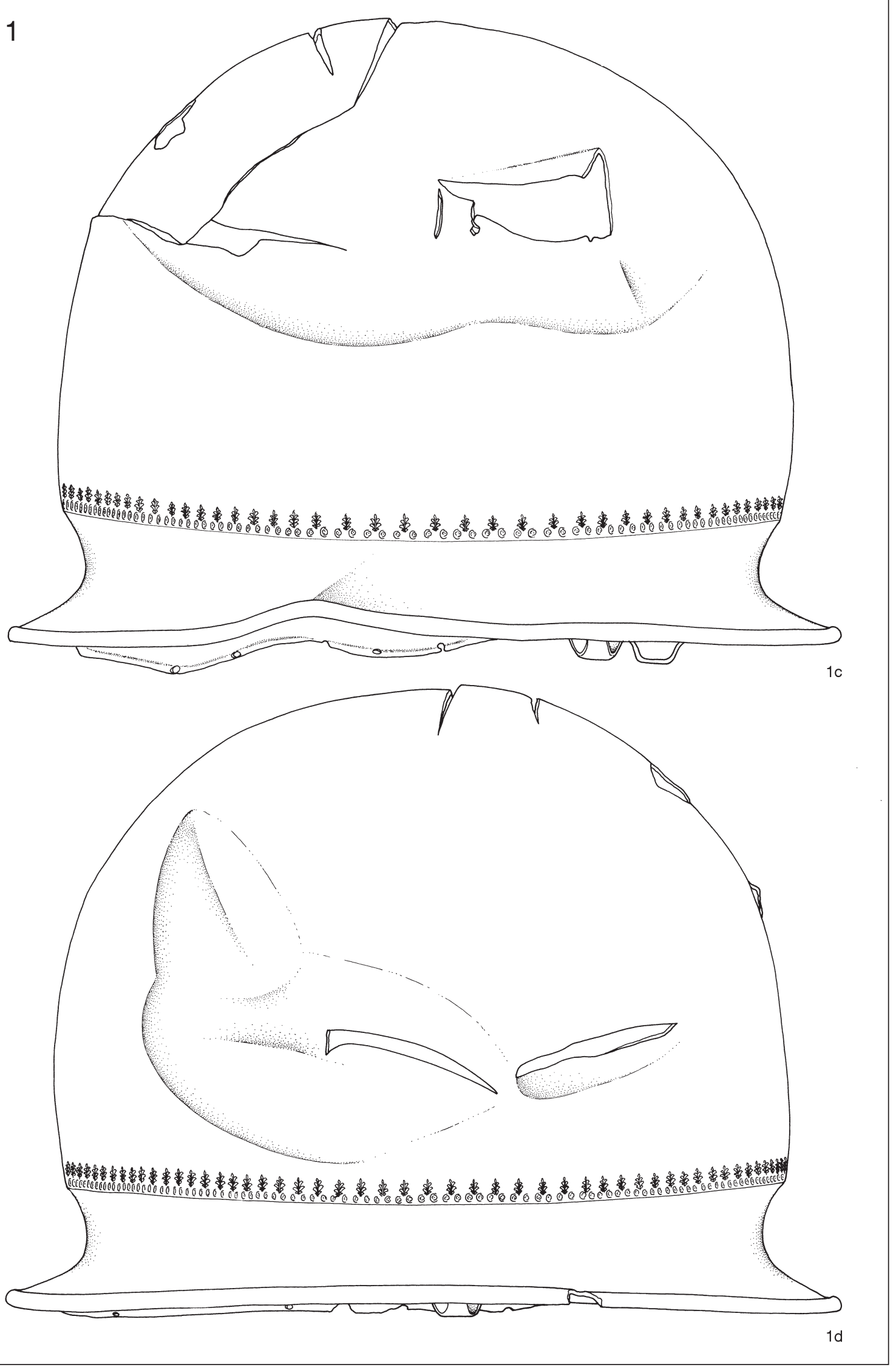

T. 2: Vrtača pri Kovku, grob 1. Bron. M. = 1:2.

Pl. 2: Vrtača near Kovk, Grave 1. Bronze. Scale $=1: 2$. 


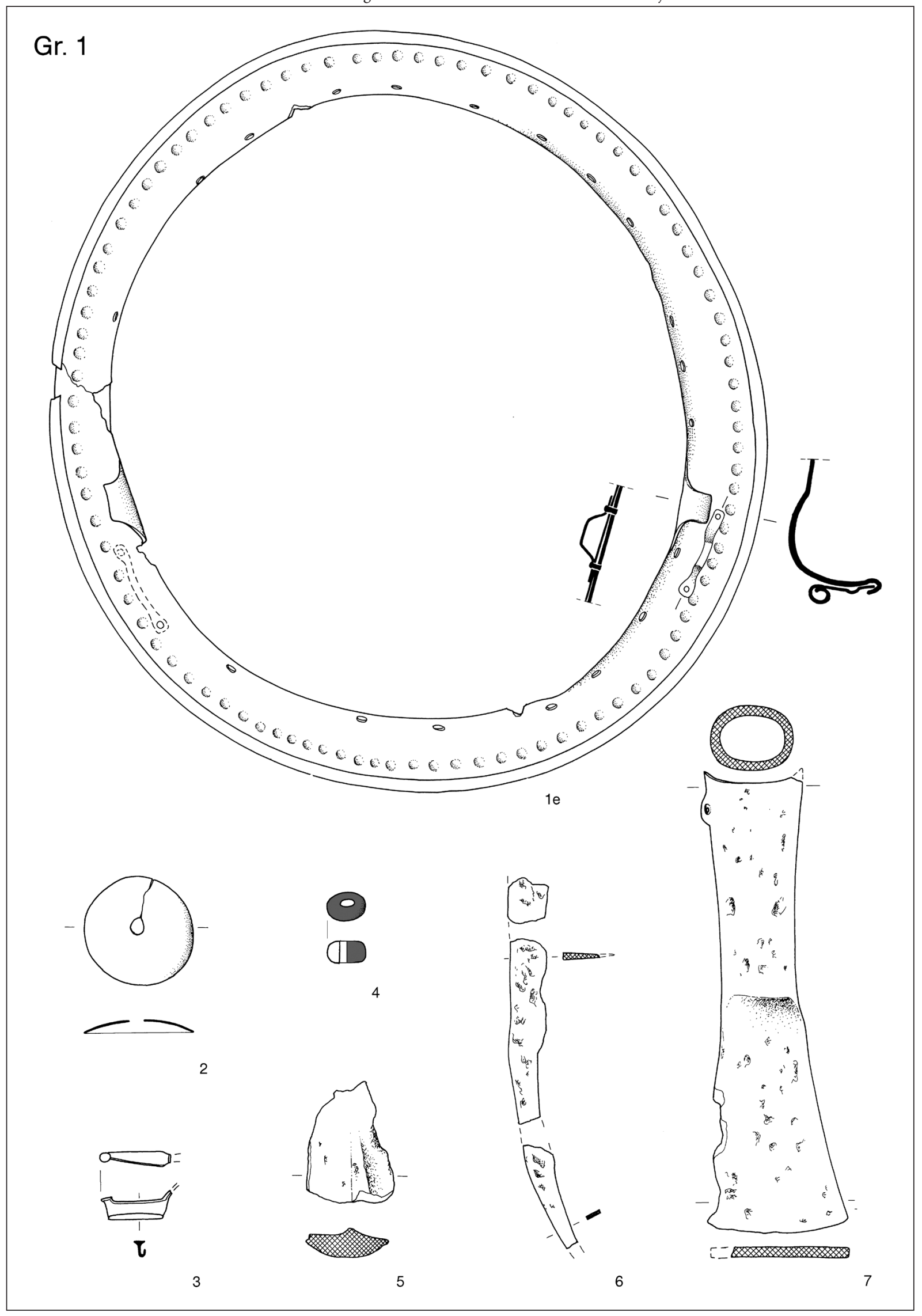

T. 3: Vrtača pri Kovku, grob 1. 1e,2,3 bron; 4 steklo; 5-7 železo. M. = 1:2.

Pl. 3: Vrtača near Kovk, Grave 1. 1e,2,3 bronze; 4 glass; $5-7$ iron. Scale = 1:2. 


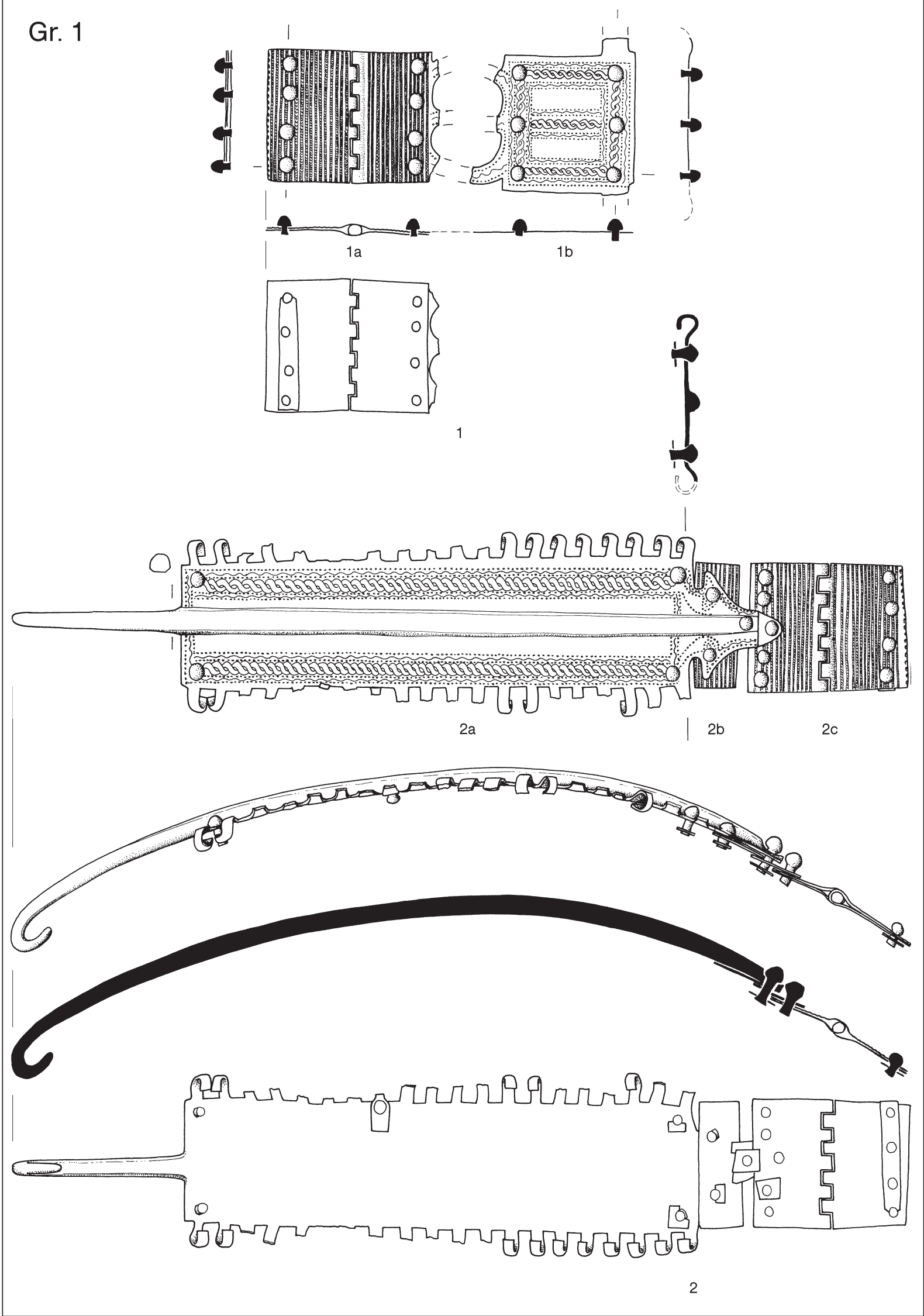

T. 4: Vrtača pri Kovku, grob 1. Bron. M. = 1:2.

Pl. 4: Vrtača near Kovk, Grave 1. Bronze. Scale = 1:2. 
Gr. 1

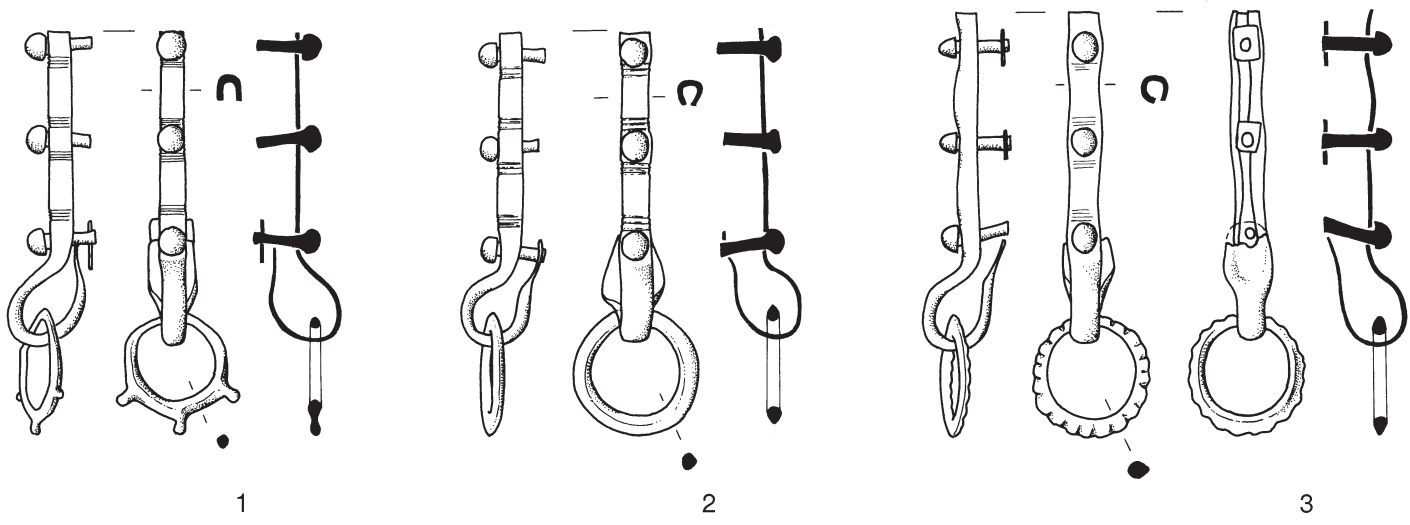

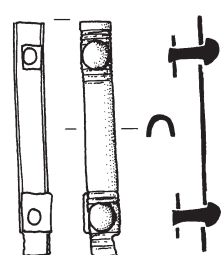

4

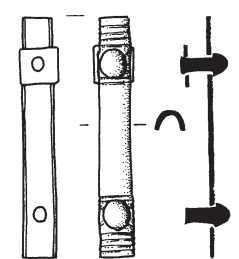

5

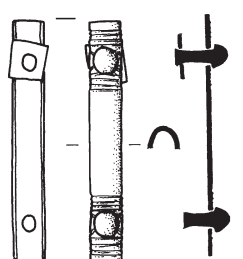

6

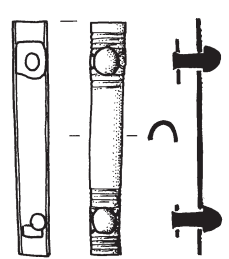

7

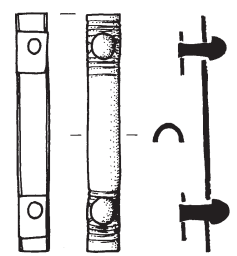

8

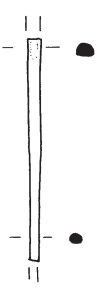

13

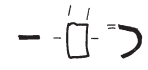

17
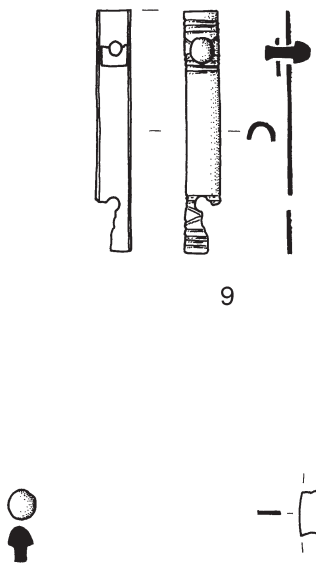

$-(-1)$

15

닌

18

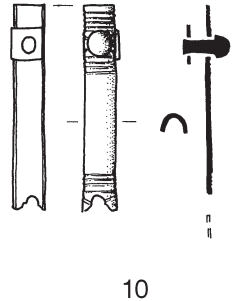

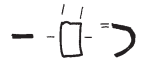

16
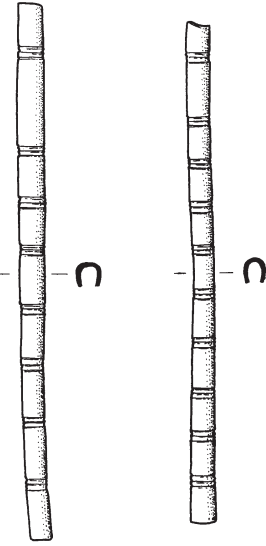

11

12

$-\int_{0}^{1} \int_{1}^{1}$

$\prod_{1} 1$

20

T. 5: Vrtača pri Kovku, grob 1. Bron. M. = 1:2.

Pl. 5: Vrtača near Kovk, Grave 1. Bronze. Scale $=1: 2$. 
Gr. 2

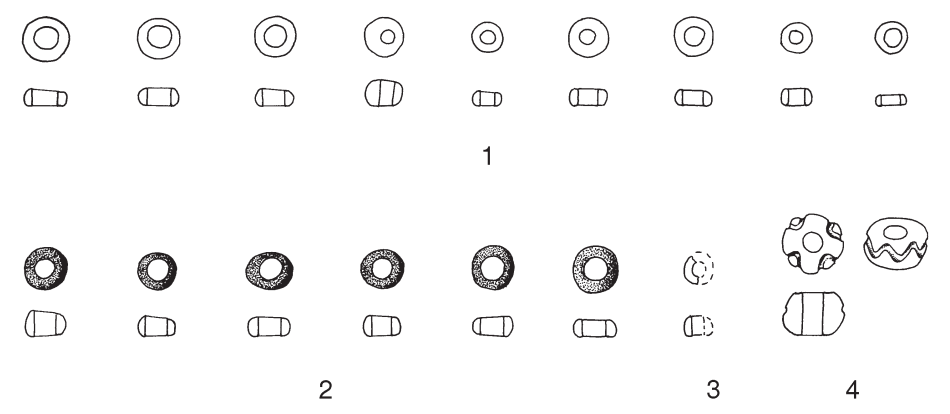
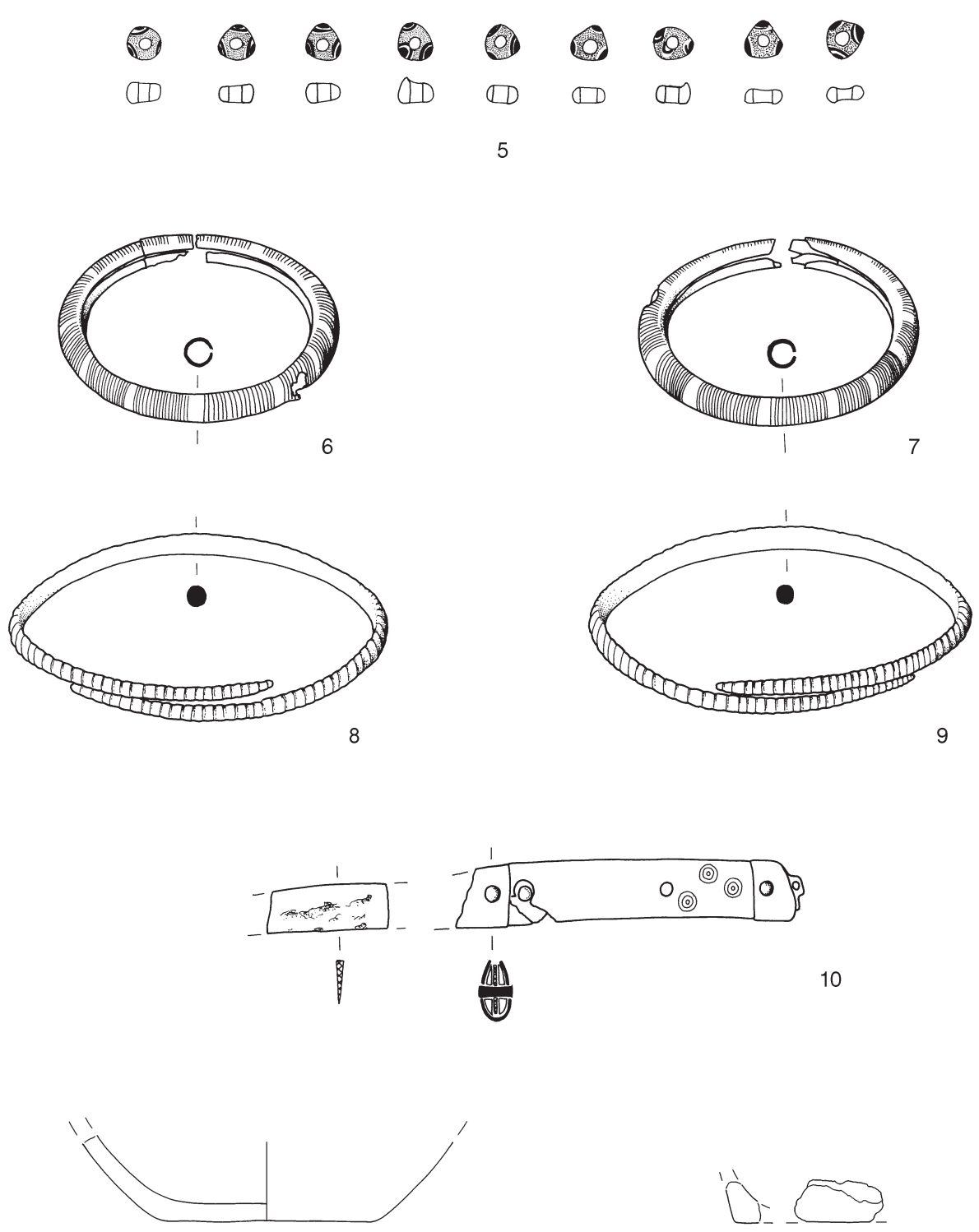

11

12

T. 6: Vrtača pri Kovku, grob 2. 1-5 steklo; 6-9 bron; 10 železo, bron in kost; 11,12 keramika. M. 1-10 =1:2; 11,12=1:4. Pl. 6: Vrtača near Kovk, Grave 2. 1-5 glass; 6-9 bronze; 10 iron, bronze and bone; 11,12 ceramics. Scale 1-10=1:2; $11,12=1: 4$ 


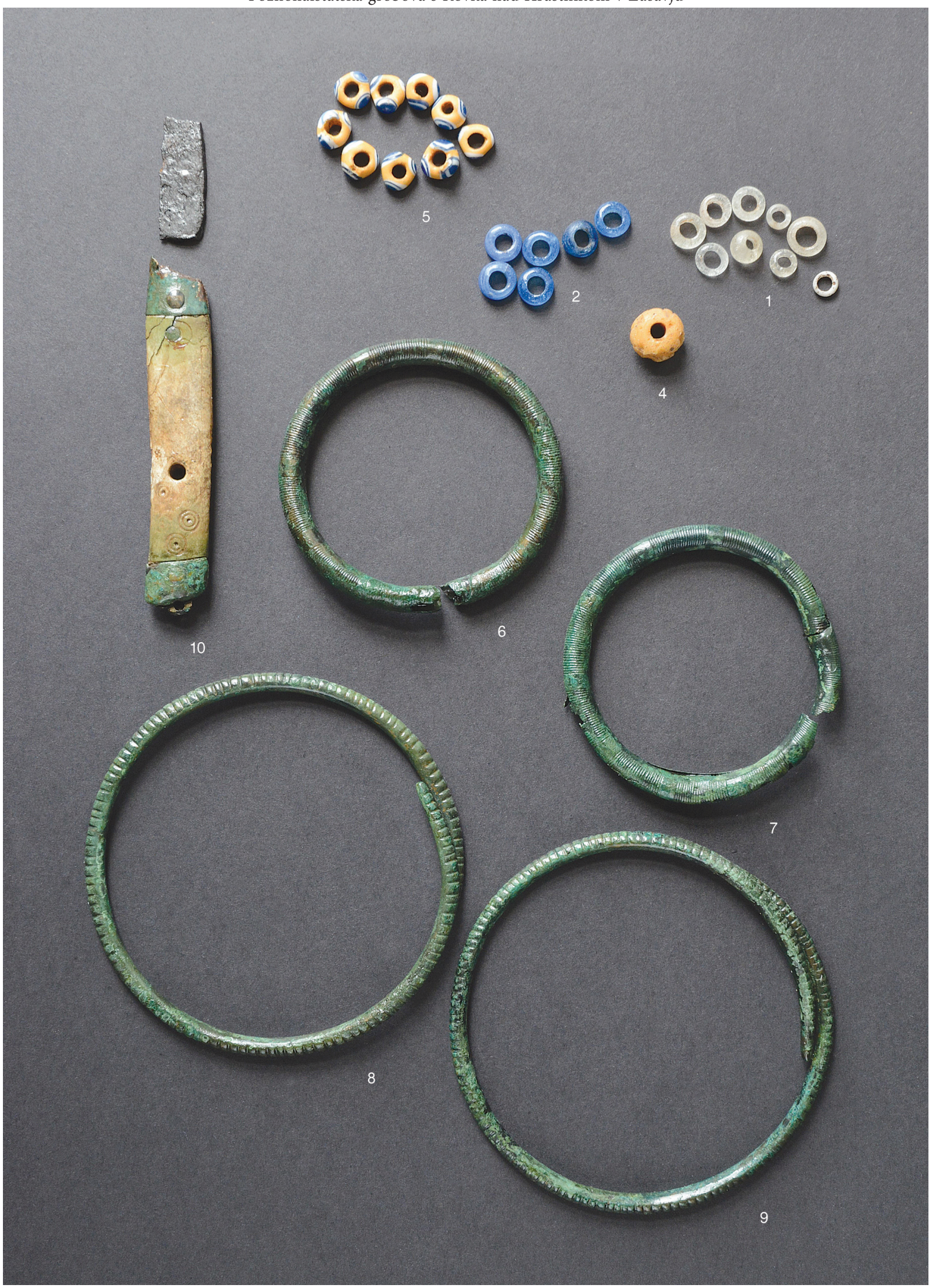

T. 7: Vrtača pri Kovku, pridatki iz groba 2.

Pl. 7: Vrtača near Kovk, goods from Grave 2. 